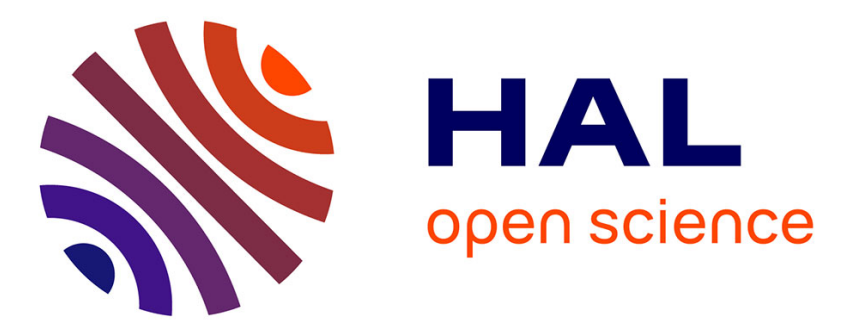

\title{
Modelling the fate of nitrite in an urbanized river using experimentally obtained nitrifier growth parameters
}

Mélanie Raimonet, Lauriane Vilmin, Nicolas Flipo, Vincent Rocher, Anniet M Laverman

\section{- To cite this version: \\ Mélanie Raimonet, Lauriane Vilmin, Nicolas Flipo, Vincent Rocher, Anniet M Laverman. Modelling the fate of nitrite in an urbanized river using experimentally obtained nitrifier growth parameters. Water Research, 2015, 73, pp.373-387. 10.1016/j.watres.2015.01.026 . hal-01136020}

\section{HAL Id: hal-01136020 \\ https: / hal.sorbonne-universite.fr/hal-01136020}

Submitted on 26 Mar 2015

HAL is a multi-disciplinary open access archive for the deposit and dissemination of scientific research documents, whether they are published or not. The documents may come from teaching and research institutions in France or abroad, or from public or private research centers.
L'archive ouverte pluridisciplinaire HAL, est destinée au dépôt et à la diffusion de documents scientifiques de niveau recherche, publiés ou non, émanant des établissements d'enseignement et de recherche français ou étrangers, des laboratoires publics ou privés. 


\title{
Modelling the fate of nitrite in an urbanized river using experimentally obtained nitrifier growth parameters
}

\author{
Mélanie Raimonet ${ }^{\mathrm{a}, 1}$, Lauriane Vilmin ${ }^{\mathrm{b}, 1}$, Nicolas Flipo ${ }^{\mathrm{b}}$, Vincent Rocher ${ }^{\mathrm{c}}$, Anniet M. \\ Laverman $^{\mathrm{a}, \mathrm{d}}$ \\ ${ }^{a}$ Sorbonne Universités, UPMC Univ Paris 06, UMR 7619, METIS, F-75005, Paris, France \\ ${ }^{b}$ Geosciences department, MINES ParisTech, PSL Research University, F-77305, Fontainebleau, France \\ ${ }^{c}$ SIAAP-Direction du Développement et de la Prospective, 82 avenue Kléber, 92700 Colombes, France \\ ${ }^{d}$ CNRS, UMR 7619, METIS, F-75005, Paris, France
}

\section{Abstract}

Maintaining low nitrite concentrations in aquatic systems is a major issue for stakeholders due to nitrite's high toxicity for living species. This study reports on a cost-effective and realistic approach to study nitrite dynamics and improve its modelling in human-impacted river systems. The implementation of different nitrifying biomasses to model riverine communities and waste water treatment plant (WWTP)-related communities enabled us to assess the impact of a major WWTP effluent on in-river nitrification dynamics. The optimal kinetic parameters and biomasses of the different nitrifying communities were determined and validated by coupling laboratory experiments and modelling. This approach was carried out in the Seine River, as an example of a large human-impacted river with high nitrite concentrations. The simulation of nitrite fate was performed at a high spatial and temporal resolution $(\Delta t=10 \mathrm{~min}, \overline{d x}=500 \mathrm{~m})$ including water and sediment layers along a $220 \mathrm{~km}$ stretch of the Seine River for a 6-year period (2007-2012). The model outputs were in good agreement with the peak of nitrite downstream the WWTP as well as its slow decrease towards the estuary. Nitrite persistence between the WWTP and the estuary was mostly explained by similar production and consumption rates of nitrite in both water and sediment layers. The sediment layer constituted a significant source of nitrite, especially during high river discharges $\left(0.1-0.4 \mathrm{mgN} h^{-1} m^{-2}\right)$. This points out how essential it is to represent the benthic layer in river water quality models, since it can constitute a source of nitrite to the water-column. As a consequence of anthropogenic emissions and in-river processes, nitrite fluxes to the estuary were significant and varied from 4.1 to $5.5 \mathrm{TN}^{-1}$ in low and high water discharge conditions, respectively, over the 2007-2012 period. This study provides a methodology that can be applied to any anthropized river to realistically parametrize autochthonous and WWTP-related nitrifier communities and simulate 
nitrite dynamics. Based on simulation analysis, it is shown that high spatio-temporal resolution hydro-ecological models are efficient to 1) estimate water quality criteria and 2) forecast the effect of future management strategies. Process-based simulations constitute essential tools to complete our understanding of nutrient cycling, and to decrease monitoring costs in the context of water quality and eutrophication management in river ecosystems.

Keywords: Nitrite, Modelling, Nitrification, WWTP, River, Water quality

\section{Introduction}

Along with the on-going improvement of nitrogen removal efficiency in Waste Water Treatment Plants (WWTPs), total nitrogen concentrations in WWTP effluents have been reduced (García-Barcina et al., 2006; Carey and Migliaccio, 2009; Rocher et al., 2011). Even though the total nitrogen load has decreased, nitrite concentrations can still exceed the European standard of good environmental status of $0.09 \mathrm{mgN} \mathrm{L}^{-1}$ in urbanized river systems (Helder and De Vries, 1983; Morris et al., 1985; von der Wiesche and Wetzel, 1998; Garnier et al., 2006; Rocher et al., 2011), as well as in agricultural ecosystems (Corriveau et al., 2010). In these anthropogenic systems, concentrations are well above $0.01 \mathrm{mgN} \mathrm{L}^{-1}$ found in pristine streams (Meybeck, 1982). Compared to nitrate, nitrite is toxic at low concentrations. A well-known consequence of nitrite toxicity is the blue baby syndrome due to direct ingestion of nitrite or to conversion of ingested nitrate to nitrite (Knobeloch et al., 2000). Maintaining low nitrite concentrations is thus a major environmental issue. However, nitrite in rivers is rarely studied independently from nitrate, due to its much lower concentration.

The presence of nitrite in aquatic systems results from its production and persistence. Nitrite is an intermediate compound produced by nitrification, denitrification and/or dissimilatory nitrate reduction to ammonium pathways in water and sediment (Wilderer et al., 1987; Kelso et al., 1997; Philips et al., 2002; Park and Bae, 2009). Nitrification is a two-step process involving two distinct microbial communities. Ammonia oxidizers (AO) transform ammonia to nitrite, and nitrite oxidizers (NO) use nitrite and generate nitrate. Ammonia oxidation is generally considered to be the limiting step (Kowalchuk and Stephen, 2001) avoiding nitrite accumulation. However nitrite has been shown to persist in oxic river waters due to low water residence time, low nitrification rates, as well as similar ammonia and nitrite oxidation rates, or non steady-state nitrification (Brion et al., 2000; Philips et al., 2002). In oxic waters of 
large rivers, benthic exchanges of nitrogen at the sediment-water interface are expected to be low due to low surface-to-volume ratios (Pinay et al., 2002). Based on this general knowledge, nitrification in the water column is supposed to be the main process affecting nitrite production and consumption in large oxic rivers, especially in high river discharge conditions. Anyhow, nitrite can be produced in river bed sediments and transferred to the water column by diffusion (Morris et al., 1985; Kelso et al., 1997). It is important to quantify the impact of this benthic nitrite production on nitrogen cycling and export to estuaries in the case of large human impacted river systems.

WWTPs constitute a potential source of nutrients e.g. nitrite as well as microorganisms (nitrifiers included) to riverine waters, depending on the processing of the influent (Servais et al., 1999a; Brion et al., 2000; Cébron et al., 2003). Species and activity of microorganims (nitrifiers included) present in WWTP effluents can differ from those found in the river upstream the effluent and alter the river ecological functioning (Goñi Urriza et al., 2000; Féray and Montuelle, 2002; Cébron et al., 2003). Consequently WWTP effluents potentially modify the nitrifying community structure and biomass, and sometimes lead to an increase in nutrient concentrations e.g. ammonium in river systems, even though treatment processes were significantly improved during the last decades. As a potential consequence, nitrifying kinetics and nitrite dynamics within the aquatic system are impacted.

Models constitute efficient integrative tools to study spatio-temporal variations of nitrogen dynamics in rivers and improve our understanding of in-river biogeochemical cycling. Many hydro-ecological models of different complexity are available (Rauch et al., 1998; Reichert, 2001; Arheimer and Olsson, 2003; Cox, 2003; Kannel et al., 2011; Sharma and Kansal, 2013). They tend to simulate a large range of biogeochemical processes, requiring a large number of parameters. However, not all models represent nitrite as an intermediate between the 2-step nitrifying process, and even less models consider explicitly the involved nitrifier biomasses. These models can be used to simulate average nitrite profiles at a pluri-annual time scale (Garnier et al., 2007), or to simulate nitrite dynamics at a high resolution along small river stretches and for a short period of time (Reichert, 2001). To our knowledge, no former study focused on nitrite dynamics at a high spatio-temporal resolution, and at large spatio-temporal scales. 
The aim of our study is to propose a cost-effective and realistic approach to study nitrification dynamics and improve the modelling of nitrogen species (and especially nitrite) in humanimpacted river systems. The Seine River is a pertinent study case for this purpose, as this river receives effluents from the biggest European WWTP (called SAV for "Seine AVal"), and is characterized by high nitrite concentrations, exceeding the good EU WFD criteria downstream this WWTP (Rocher et al., 2011). Nitrogen removal in the SAV WWTP has significantly increased since the addition of nitrification and denitrification units in 2007 and 2011, and changed the nitrogen dynamics in the Seine River (Rocher et al., 2011). These modifications most likely changed kinetic parameters of nitrifying communities in the SAV effluent, as well as the subsequent nitrite dynamics within the Seine River downstream SAV.

The originality of this study is the distinction between natural river and WWTP nitrifying communities. The biomass and kinetic parameters of each river and WWTP-related nitrifying community were characterized using a cost-effective approach. (1) Potential ammonia and nitrite oxidation activity in river and WWTP waters were studied separately using batch incubations with inhibitors for the two processes. The evolution of nitrite concentrations with a lumped model representing the 2-step nitrification process were then fitted in order to determine optimal values of biomass and kinetic parameters (maximal growth rate, half-saturation constant) of ammonia and nitrite oxidizers. (2) Experimentally deduced biomass and kinetic parameters defined for riverine and WWTP-related nitrifying communities were validated in a hydro-ecological model of the Seine River including water and sediment layers along a $220 \mathrm{~km}$ stretch for a 6-year period (2007-2012). This allowed the assessment of WWTP impact on the fate of nitrite and nitrifiers along a human-impacted river. Nitrogen mass balances were assessed up- and downstream the WWTP for different hydrological conditions. The model was used to quantify the effect of benthic and pelagic processes on nitrite fluxes exported to the estuary, and to forecast the effect of new management strategy impacts on river water quality.

\section{Methods}

\subsection{Study site}

The Seine River is the second longest French river (776 km long), which flows north-west towards the English Channel. The climate is temperate, with oceanic and semi-continental influences. The mean annual discharge is $210 \mathrm{~m}^{3} \mathrm{~s}^{-1}$ in Paris for the period 1978-2011. Over 
this time period, the first discharge decile is $90 \mathrm{~m}^{3} \mathrm{~s}^{-1}$ (discharge lower than this value 10 $\%$ of the time), while the last one is $670 \mathrm{~m}^{3} \mathrm{~s}^{-1}$. The summer river discharge is artificially maintained at its value in Paris from upstream water release reservoirs. Two major tributaries are the Marne and Oise Rivers, with an average discharge of 95 and $100 \mathrm{~m}^{3} \mathrm{~s}^{-1}$, respectively. Water temperatures range from $5{ }^{\circ} \mathrm{C}$ in winter to $25^{\circ} \mathrm{C}$ in summer. The Seine River is a highly anthropized system dominated by agriculture, urbanization and industry. Downstream Paris, the Seine River is strongly impacted by urbanization with a population of 12 million inhabitants concentrated over an area of about $12,000 \mathrm{~km}^{2}$ (Fig. 1). The biggest Parisian and European WWTP (SAV) is located downstream of Paris and treats waste water from more than 5 million population equivalent (treatment capacity of $1.710^{6} \mathrm{~m}^{3} \mathrm{~d}^{-1}$ ) (Rocher et al., 2011). In 2007, a tertiary biological treatment composed of a nitrification/denitrification unit was implemented in the SAV WWTP for $70 \%$ nitrogen removal.

\subsection{Sampling design}

River water samples (10-20 L) were collected in November 2012 upstream SAV (at Asnières), and in the SAV effluent (Fig. 1). Samples were brought back to the laboratory after sampling and stored at $4{ }^{\circ} \mathrm{C}$ in the dark. Aliquots were immediatly filtered over $0.2 \mu \mathrm{m}$ PVDF filters and analyzed for nitrite concentrations.

\subsection{Laboratory incubations and analyses}

Unfiltered water samples (200-250 mL) were incubated in Erlenmeyers of $500 \mathrm{~mL}$ in the dark at $20{ }^{\circ} \mathrm{C}$ under constant agitation $(120 \mathrm{rpm})$ for 14 days. According to Cébron and Garnier (2005), two selective inhibitors, i.e. allylthiourea (0.1 mM) and sodium chlorate (10 mM), were used to study separately $\mathrm{NH}_{4}^{+}$and $\mathrm{NO}_{2}^{-}$oxidation reactions. Aliquots were sampled daily to measure $\mathrm{NO}_{2}^{-}$concentrations. Additional water samples were incubated in the presence of the two inhibitors to verify the complete nitrification inhibition. Samples from both sites were also ammended with $\mathrm{NH}_{4}^{+}\left(14 \mathrm{mgN} \mathrm{L}^{-1}\right)$ and incubated to observe $\mathrm{NO}_{2}^{-}$dynamics with active (non-inhibited) ammonia and nitrite oxidizers. The concentrations of $\mathrm{NO}_{2}^{-}$were determined using the colorimetric method of Rodier (1984). 


\subsection{Nitrification model (C-RIVE)}

The nitrification processes in the incubated water samples were simulated with the C-RIVE model (Vilmin et al., 2012), the stand-alone version of the biogeochemical module of the ProSE hydro-ecological model (see section 2.6). C-RIVE is an adaptation of the RIVE model (Billen et al., 1994; Garnier et al., 1995), which mimics carbon, nitrogen, phosphorus and oxygen cycling in river systems. Living species involved in these biogeochemical cycles, as nitrifiers, are explicitely represented. The nitrification process has recently been detailed in RIVE and C-RIVE models, including the appearance of nitrite and nitrous oxide intermediates (Cébron et al., 2005; Garnier et al., 2007; Polus et al., 2011; Vilmin et al., 2012).

A brief description of the formulation used to describe the nitrification processes is given here. Description, unit and fixed value for parameters and variables are given in Table 1. The evolution of nitrifier biomass $[B N]_{i, j}$ is determined by nitrifier growth and mortality, and depends on temperature, $\mathrm{NH}_{4}^{+}$or $\mathrm{NO}_{2}^{-}$, and $\mathrm{O}_{2}$ concentrations (Eq. 1, as described by Polus et al. (2011)).

$$
\frac{\mathrm{d}[B N]_{i, j}}{\mathrm{~d} t}=\left(\mu_{i, j}-\text { mort }_{i}-\frac{V_{s e d, i}}{h}\right)[B N]_{i, j}
$$

$i$ is the index referring to the nitrifying community, i.e. ammonia oxidizers $(A O)$ or nitrite oxidizers $(N O), j$ is the index refering to the sample location (river water or SAV effluent). Note that the sedimentation velocity $V_{\text {sed }, i}$ is set to zero for the simulations of the incubated water samples, as these samples are agitated during the experiment.

Growth rates of ammonia and nitrite oxidizers $\left(\mu_{i, j}\right)$ are calculated according to the following equations 2 and 3 (Garnier et al., 2007):

$$
\begin{aligned}
& \mu_{A O, j}=\mu_{\max , A O, j} f(T)\left(\frac{\left[N H_{4}^{+}\right]}{\left[N H_{4}^{+}\right]+K_{N H_{4}^{+}, j}}\right)\left(\frac{\left[O_{2}\right]}{\left[O_{2}\right]+K_{O_{2}, A O}}\right) \\
& \mu_{N O, j}=\mu_{\max , N O, j} f(T)\left(\frac{\left[N O_{2}^{-}\right]}{\left[N O_{2}^{-}\right]+K_{N O_{2}^{-}, j}}\right)\left(\frac{\left[O_{2}\right]}{\left[O_{2}\right]+K_{O_{2}, N O}}\right)
\end{aligned}
$$

with a temperature dependance described by the following equation (Polus et al., 2011): 


$$
f(T)=f\left(T_{\mathrm{opt}}\right) \mathrm{e}^{-\frac{\left(T-T_{\mathrm{opt}, i}\right)^{2}}{\sigma_{i}^{2}}}
$$

The quantity of consumed ammonium, nitrite and oxygen depends on growth rates $\mu_{i, j}$, nitrification yields $Y_{i}$ and nitrifier biomass $[B N]_{i, j}$ according to the following equations (Eqs. $5,6$ and 7$)$.

$$
\begin{aligned}
\frac{\mathrm{d}\left[D I N_{\text {cons }}\right]}{\mathrm{d} t} & =-\sum_{j} \frac{\mu_{i, j}}{Y_{i}}[B N]_{i, j} \\
\frac{\mathrm{d}\left[D I N_{\text {prod }}\right]}{\mathrm{d} t} & =+\sum_{j} \frac{\mu_{i, j}}{Y_{i}}[B N]_{i, j} \\
\frac{\mathrm{d}\left[O_{2}\right]}{\mathrm{d} t} & =-\sum_{j} r_{O_{2}, i} \frac{\mu_{i, j}}{Y_{i}}[B N]_{i, j}
\end{aligned}
$$

where $D I N_{\text {cons }}$ and $D I N_{\text {prod }}$ are $\mathrm{NH}_{4}^{+}$and $\mathrm{NO}_{2}^{-}$for ammonia oxidizers, and $\mathrm{NO}_{2}^{-}$and $\mathrm{NO}_{3}^{-}$ for nitrite oxidizers.

\subsection{Fitting procedure}

Optimal values of initial $[B N]_{i, j}, \mu_{\max , i, j}, K_{N H_{4}^{+}, j}$ and $K_{N O_{2}^{-}, j}$ were obtained by fitting nitrite concentrations in non-inhibited and/or inhibited incubations. The fitting was achieved with a screening of the model response to a large number of parameter sets. The minimization of the root mean square error (RMSE) between experimental and modelled values was used as the objective function to determine the optimal values. Table 1 displays the ranges and the optimal values of parameters $[B N]_{i, j}, \mu_{m a x, i, j}, K_{N H_{4}^{+}, j}$ and $K_{N_{2}^{-}, j}$. Mortality rates, nitrification yields and the temperature dependency function $\left(T_{\mathrm{opt}, i}\right.$ and $\left.\sigma_{i}\right)$ were previously determined (Brion and Billen, 1998; Garnier et al., 2007), and were therefore kept constant in the current fitting procedure.

A flow chart explains the different steps to obtain optimal parameters (Fig. 2). Noninhibited water samples were incubated for 2 weeks. The observed $\mathrm{NO}_{2}^{-}$time-series were analysed to determine if a second batch incubation was necessary to determine nitrifier growth kinetic parameters and biomass. Two cases were considered : 
- $\mathrm{NH}_{4}^{+}$and $\mathrm{NO}_{2}^{-}$oxidation did not occur simultaneously in the non-inhibited water sample. In this case, the whole initial amount of $\mathrm{NH}_{4}^{+}$was converted to nitrite during the first days of the incubation. $\mathrm{NO}_{2}^{-}$concentration reached the maximum possible value of 14 $\mathrm{mgN} \mathrm{L}{ }^{-1}$ (corresponding to the initial concentration of $\mathrm{NH}_{4}^{+}$) before it started to decrease due to $\mathrm{NO}_{2}^{-}$oxidation (see Seine River water sample, Fig. 3a).

- $\mathrm{NH}_{4}^{+}$and $\mathrm{NO}_{2}^{-}$oxidation occured simultaneously. $\mathrm{NO}_{2}^{-}$concentration therefore did not reach the maximal value of $14 \mathrm{mgN} \mathrm{L}^{-1}$ (see SAV water sample, Fig. 3b).

In the first case, one single incubation was needed. Growth parameters and biomass of ammonia oxidizers were first fitted from the beginning of the batch experiment to the $14 \mathrm{mgN}$ $\mathrm{L}^{-1} \mathrm{NO}_{2}^{-}$concentration peak (first 8 days, see Seine River water sample, Fig. 3a). Nitrite oxidation was then fitted until the end of the batch experiment (days 9 to 15).

In the second case, the non-inhibited incubation did not allow identifying ammonia and nitrite oxidizer parameters separately. An additional incubation, inhibiting nitrite oxidation, was used to determine biomass and kinetic parameters of ammonia oxidizers. Using the values obtained for ammonia oxidizers, biomass and kinetic parameters of nitrite oxidizers were then determined in the non-inhibited batch. During this calibration of nitrite oxidation, a dimensionless acceleration factor $\left(r_{A O}\right)$ of maximal growth rates was used for ammonia oxidizers. This factor was used and justified by the fact that nitrite production was slightly lower in inhibited compared to non-inhibited batches (see SAV water sample, Fig. 3b), most likely due to higher mortality rates of ammonia oxidizers or to lower maximal growth rates in the presence of the inhibitor. A similar factor was used to account for increased degradation efficiencies of organic carbon under oxic versus anoxic conditions (Canavan et al., 2006).

\subsection{Hydro-ecological model (PROSE)}

The nitrifying growth parameters and biomasses obtained with the procedure described above were implemented and validated in the PROSE hydro-ecological model to simulate nitrification dynamics along a $220 \mathrm{~km}$ stretch of the Seine River for a 6-year period (2007-2012). The domain started $10 \mathrm{~km}$ upstream Paris down to Poses at the entrance of the Seine Estuary (Fig. 1), including $25 \mathrm{~km}$ of the Marne River. Four major tributaries were taken into account as boundary conditions. Anthropogenic pressures (WWTP effluents, combined sewer overflows 
and dry weather effluents) constituted point sources in the model (Even et al., 1998, 2004, 2007b)

The PRoSE model simulates the hydro-ecological response of a river system to point sources or diffuse pollutions, in steady or transient states (Even et al., 1998, 2007b; Flipo et al., 2004). It is composed of three modules, which compute hydrodynamic, transport and biogeochemical processes, in the column water and the benthic sediment. The ProSe model has been applied successfully to several case studies in the Seine River basin (Even et al., 1998, 2004, 2007b; Flipo et al., 2004, 2007; Polus et al., 2010, 2011; Vilmin et al., in press) and in the Seine Estuary (Even et al., 2007c). The role of benthic sediments has been recently improved by recalibration of the sediment erosion processes in the ProSE model (Vilmin et al., 2015).

In addition to nitrification (described in section 2.4), the model simulates the fate of ammonium via heterotrophic mineralization of organic matter and phytoplankton uptake. Nitrate concentrations are affected by phytoplankton uptake and by denitrification. In the model, nitrite is considered as the intermediate variable in the nitrification process, whereas incomplete denitrification is not considered in the present study.

Simulated time series of $\mathrm{NH}_{4}^{+}, \mathrm{NO}_{2}^{-}$and $\mathrm{NO}_{3}^{-}$concentrations were validated at four weekly monitoring stations (from upstream to downstream: Asnières, Sartrouville, Poissy, Poses) managed by the public sewage company of Paris (Syndicat Interdépartemental pour l'Assainissement de l'Agglomération Parisienne, SIAAP). Note that the biggest WWTP (SAV) is located between Sartrouville and Poissy. The longitudinal profiles of the simulated concentration quantiles (10\%, $50 \%$ and $90 \%)$ were compared to weekly observations at ten stations managed by the SIAAP and eight stations of the national river monthly monitoring network (Réseau de Contrôle et de Surveillance, referred to as RCS) along the studied stretch. The longitudinal profiles of the biomasses of ammonia and nitrite oxidizers from the Seine River and the SAV effluent were compared at low and high water discharge conditions, following the approach developed to analyze in-river sediment (Vilmin et al., 2015) and phosphorus (Vilmin et al., in press) dynamics. The distinction between low and high discharge conditions was based on the daily discharge measured at the Paris gauging station (Fig 1). Discharge rates lower and higher than $205 \mathrm{~m}^{3} \mathrm{~s}^{-1}$ (median discharge rate for the 2007-2012 period) were defined as low and high river discharge conditions, respectively. 
Finally, nitrogen budgets were derived from model outputs for low and high water discharge conditions over the simulated 6-year period. Nitrogen stocks were calculated in two compartments (water column and sediment layer) in two river domains (upstream and downstream the SAV WWTP). Nitrogen fluxes linked to the different simulated biogeochemical processes and exchanges at the sediment-water interface were calculated as model outputs and integrated over the two river domains (upstream and downstream the SAV WWTP). Averaged daily fluxes for the simulated 6-year period were calculated in each domain for low and high water discharge condition, respectively.

\section{Results}

\subsection{Optimal sets of biomasses and kinetic parameters of natural nitrifying communities in} in-river waters and WWTP effluents

The best statistical adjustments of nitrite concentrations over 15 days in batch incubations are shown for ammonia and nitrite oxidizers in river water and SAV effluent (Fig. 3). Modelled nitrite outputs were in good agreement with measured nitrite concentrations, when using the optimal parameter sets for Seine water (correlation $=0.93$ and $\mathrm{RMSE}=2.32 \mathrm{mgN} \mathrm{L}^{-1}-0.44$ $\mathrm{mgN} \mathrm{L}^{-1}$ without the point at day 8) and for SAV effluent non-inhibited batches (correlation > 0.99 and $\left.\mathrm{RMSE}=0.01 \mathrm{mgN} \mathrm{L}^{-1}\right)$. The optimal values of nitrifier biomass $[B N]_{i, j}(0.001-0.02$ mgC L $\left.{ }^{-1}\right)$, maximal growth rate $\mu_{\max , i, j}\left(0.04-0.07 \mathrm{~h}^{-1}\right)$ and half-saturation constant $K_{N H_{4}^{+}, j}$ (1.5-2 $\left.\mathrm{mgN} \mathrm{L}^{-1}\right)$ and $K_{\mathrm{NO}_{2}^{-}, j}\left(0.3-10 \mathrm{mgN} \mathrm{L}^{-1}\right)$ are summarized in Table 1. Our values observed for natural communities under reconstructed in situ conditions were in the range of values determined for pure cultures under optimal conditions i.e. $[B N] \in[0.00004-0.07] \mathrm{mgC} \mathrm{L}^{-1}$, $\mu_{\max } \in[0.008-0.1] \mathrm{h}^{-1}, K_{N H_{4}^{+}} \in[0.002-74] \mathrm{mgN} \mathrm{L}^{-1}$ and $K_{N O_{2}^{-}} \in[0.00003-28] \mathrm{mgN} \mathrm{L}^{-1}$ (Tables 2 and 3). The estimated ammonia oxidizer biomass $\left(\left[B N_{A O}\right]\right)$ was higher than nitrite oxidizer biomass $\left([B N]_{N O}\right)$ in both WWTP and river samples. The SAV WWTP effluent contained one to two orders of magnitude more nitrifying biomass $\left(0.027\right.$ and $0.008 \mathrm{mgC} \mathrm{L}^{-1}$ for ammonia and nitrite oxidizers, respectively), as deduced from the experiments, than the Seine River water (0.0075 and $0.001 \mathrm{mgC} \mathrm{L}^{-1}$ for ammonia and nitrite oxidizers, respectively). The maximal growth rate $\left(\mu_{\max }\right)$ was in the same order of magnitude for ammonia oxidizers and nitrite oxidizers in river and WWTP samples $\left(0.04-0.07 \mathrm{~h}^{-1}\right)$. As found in the literature, $K_{N H_{4}^{+}}$and especially $K_{N_{2}^{-}}$were more variable than $\mu_{\max }$ values. $K_{N H_{4}^{+}}$values were similar in river and 
SAV samples (2 and $1.5 \mathrm{mgN} \mathrm{L}{ }^{-1}$, respectively), while $K_{\mathrm{NO}_{2}^{-}}$values were 30 times higher in river waters than in SAV effluent (10 and $0.3 \mathrm{mgN} \mathrm{L}^{-1}$, respectively).

\subsection{Validation of the optimal sets of parameters in an hydro-ecological model along a $220 \mathrm{~km}$ stretch for a 6-year period}

The optimal parameter sets determined for ammonia and nitrite oxidizing communities in river water and SAV effluent were then used to parametrize the ProSE model. The 6-year outputs of $\mathrm{NO}_{2}^{-}$concentrations are presented for 4 stations from upstream to downstream the SAV WWTP and compared with weekly data collected at SIAAP stations (Fig. 4). Good adjustments of $\mathrm{NO}_{2}^{-}$concentration time-series were observed upstream the SAV WWTP effluent (Asnières, Sartrouville) for the whole 6-year simulated period, at low river discharge $\left(\mathrm{RMSE}<0.034 \mathrm{mgN} \mathrm{L}^{-1}\right.$ ) and high discharge conditions (RMSE $<0.015 \mathrm{mgN} \mathrm{L}^{-1}$; Table 4). Representing two distinct nitrifying communities (river and WWTP) led to an accurate simulation of concentrations downstream the SAV WWTP (Poissy, Poses), especially during high river discharge periods $\left(\mathrm{RMSE}<0.057 \mathrm{mgN} \mathrm{L}^{-1}\right.$; Table 4). A slight overestimation of $\mathrm{NO}_{2}^{-}$ concentrations was sometimes observed at Poses, due to less well constrained river morphology upstream this station, which involves uncertainties in the location of benthic river sediments. Vilmin et al. (2015) validated sediment transport downstream the WWTP, but not so far in the downstream area of the river system, due to the lack of geomorphological data. Uncertainties in the location of benthic river sediments may induce uncertainty in nitrification rates within fluid sediments at this station. However, all the stations upstream this location show good adjustments (similar to those observed at Poissy). Simulated $\mathrm{NH}_{4}^{+}$and $\mathrm{NO}_{3}^{-}$were also validated along the $220 \mathrm{~km}$ stretch (see Appendix Figs. A.1 and A.2).

\subsection{Assessment of in-river water-quality}

Longitudinal profiles of $10 \%, 50 \%$ and $90 \%$ concentration quantiles for the 2007-2012 period were calculated with the ProSE model for $\mathrm{NH}_{4}^{+}, \mathrm{NO}_{2}^{-}$, and $\mathrm{NO}_{3}^{-}$(Fig. 5). The spatial variability of these quantiles was high around point source effluent output. Regarding nitrite concentrations, the water quality status moved from moderate to bad status just downstream the SAV WWTP, and before the confluence with the Oise River. Nitrite concentrations increased slightly along the first $100 \mathrm{~km}$ after the Oise River, before decreasing towards the estuary. 
Using distinct variables for river and WWTP nitrifiers in the hydro-ecological ProSE model also allowed simulating the fate of the biomass of each nitrifying community issued from the two main sources (i.e. upper drainage basin, WWTP effluent) in the Seine hydrological system (Fig. 6). Nitrifiers from the SAV WWTP contributed to $16-76 \%$ of the nitrifying biomass present in the river downstream the SAV effluent, especially in low river discharge conditions $(50-76 \%)$.

\subsection{Effect of sampling frequency on river environmental assessment}

Although simulated times series were validated with weekly monitoring data (Fig. 4), $\mathrm{NH}_{4}^{+}, \mathrm{NO}_{2}^{-}$, and $\mathrm{NO}_{3}^{-}$concentrations calculated by the model were compared to the values measured at a monthly time step at the RCS sampling station located at Meulan (longitudinal abscisse $=100 \mathrm{~km}$, Fig. A.3). The model provided accurate estimates of in-river $\mathrm{NH}_{4}^{+}$, $\mathrm{NO}_{2}^{-}$, and $\mathrm{NO}_{3}^{-}$concentrations of monthly sampled waters. $\mathrm{NH}_{4}^{+}$concentrations showed highfrequency variability which was not accounted for by monthly sampling. Low $\mathrm{NO}_{2}^{-}$variations were observed upstream the SAV WWTP, but its variability increased downstream. The model reproduced well the observed concentrations at the sampling dates (with correlation coefficients at Meulan of 0.88 and 0.71 for $\mathrm{NH}_{4}^{+}$and $\mathrm{NO}_{2}^{-}$concentrations, respectively). Nevertheless the monthly measurement captured only few peaks during the study period, which had an effect on the deduced statistical criteria. The $90 \%$ quantiles for $\mathrm{NH}_{4}^{+}$and $\mathrm{NO}_{2}^{-}$concentrations estimated with the PROSE model $(d t=10 \mathrm{~min})$ were therefore greater than those estimated with the monthly sampling data. Nitrate showed very low short-term variability.

\subsection{Testing the effect of new treatment strategy}

A simulation with no nitrifying biomass in the SAV effluent was performed to mimic the implementation of effluent micro-filtration (Fig. 4). Without nitrifiers in the SAV effluent, nitrite concentrations would reach values corresponding to a bad ecological status according to the European WFD along almost the whole stretch from SAV to the estuary. According to the model results, mean nitrite concentrations at the estuary would increase by over $60 \%$ without the input of nitrifying biomass from the WWTP. 


\section{Discussion}

\subsection{Fitting nitrifying parameters to model the fate of nitrite in human-impacted rivers}

Our approach combines deduction of kinetic parameters using laboratory experiments and stand-alone modelling, and validation of these parameters in hydro-ecological modelling in order to upscale our results from laboratory to river scale. This approach is consequently based on identical nitrification model frames in stand-alone and river-scale models.

Our results highlight the importance of determining biomasses and kinetic parameters of natural nitrifying communities in rivers and in point source effluents carrying active nitrifiers, i.e. in WWTPs. The higher nitrifying biomass in WWTP effluents compared to river water (this study) is explained by tertiary biological treatments removing nitrogen in urban effluents and the presence of nitrifying biomass in the WWTP. These higher biomasses are in agreement with previous results found when WWTP was only subjected to secondary treatments (Servais et al., 1999b; Brion and Billen, 1998; Cébron et al., 2003). This suggests that the release of nitrifying biomasses related to WWTP effluents must be considered, when microfiltration, chlorine or ultraviolet radiation is not performed at the outlet. This biomass must be characterized depending on the treatment applied in WWTPs.

In addition to biomass estimation, our method enables the determination of kinetic parameters and can be applied to any riverine ecosystem. These parameters are necessary to calculate the nitrifying activity, which appears to be more important than the nitrifying biomass itself (Röling, 2007). The low variability of the maximal growth rate $\left(0.04-0.07 \mathrm{~h}^{-1}\right)$, which is consistent with the literature, suggests a robust parametrization of this parameter and a low variability of growth rates depending on nitrifying communities (ammonia or nitrite oxidizers) and on their origin (river or WWTP). Considering a constant mortality, the range of maximal growth parameters can easily be transfered to any system, and tuned if necessary. The difference in affinity $\left(K_{\mathrm{NO}_{2}^{-}}\right)$between river and WWTP (10 and $0.3 \mathrm{mgN} \mathrm{L}{ }^{-1}$, respectively) is most likely related to variations in nitrifying community structure, and environmental conditions. The low $K_{\mathrm{NO}_{2}^{-}}$in tertiary advanced WWTP effluent might be explained by the dominance of Nitrobacter species, as already observed in the SAV WWTP effluents prior to 2007 (Cébron and Garnier, 2005), and in 2012 (T. Cazier, pers. comm.). Nitrobacter sp. has already been shown to exhibit low $K_{\mathrm{NO}_{2}^{-}}$in activated sludge reactors (Jiménez et al., 2011) and in $1000 \mathrm{mgN} \mathrm{L}^{-1}$ 
enriched synthetic waste water (Blackburne et al., 2007). The similarity of $\mathrm{K}_{\mathrm{NO}_{2}^{-}}$obtained in WWTP-type chemostat (Cébron et al., 2005) and in SAV WWTP effluent (our study) suggests that nitrifying communities in tertiary advanced WWTP effluents might be characterized by low $K_{\mathrm{NO}_{2}^{-}}$. The high $K_{\mathrm{NO}_{2}^{-}}$in river waters, in the range of values found in the literature (Table 3), might rather be explained by other reasons e.g. species competition, or limitations other than nitrite.

Our results bring complementary information on the difference between river and WWTPrelated nitrifying communities, leading to improvements in the modelling of nitrite dynamics and nitrogen cycling in the river. Our approach is based on several initial assumptions from previous experimental and modelling studies in the Seine River (Brion and Billen, 1998; Cébron et al., 2005; Garnier et al., 2007): a constant mortality rate of $0.01 \mathrm{~h}^{-1}$, a yield of 0.09 and 0.026 $\mathrm{mgC} \mathrm{mgN}^{-1}$ for ammonia and nitrite oxidizers, respectively, and a temperature function (see Eq. 4) with $T_{\text {opt }}$ of $23{ }^{\circ} \mathrm{C}$ and $\sigma$ of $12{ }^{\circ} \mathrm{C}$. The fixed mortality rate (i.e. first-order mortality constant) strongly controls the growth rate value, but it does not impact the net growth rate of nitrifiers (i.e. growth - mortality). More experimental studies should be undertaken to precise the spatio-temporal variations of yields and temperature functions suggested in other studies (detailed here after), which could potentially affect nitrite dynamics in the river. First, even if protein synthesis is essential to maintain optimal nitrifying activity (Tappe et al., 1999), yields have been shown to vary with temperature and oxygen, suggesting the potential uncoupling between nitrifier growth and activity (Andersson et al., 2006). Second, optimal temperatures for growth generally range between 20 and $35{ }^{\circ} \mathrm{C}$ depending on species, and can vary with the seasonal nitrifier community composition. To date, no dataset exists to constrain the variability of yields and temperature functions with environmental parameters and community composition. However, the good adjustment of nitrogen species in our study suggests that spatio-temporal variations of yields and temperature functions might have been low or might be well represented by generic and constant parameters. The use of generic parameter values is thus validated which is in adequation with the deterministic approach generally used in river modelling.

As modelling is based on initial assumptions, it is essential to use identical initial assumptions in stand-alone models and fully coupled hydro-ecological models to achieve a good param- 
eterization of ecosystem models. In our case, we used the same initial assumptions of constant mortality rates, yields and temperature function parameters during the fitting procedure in the batch model (C-RIVE) and during the 6-year simulation performed with the hydro-ecological model (ProSE-C-RIVE).

Our approach could be applied to any river system, using an hydro-ecological model which takes into account point sources e.g. WWTP effluents. The minimum required is to consider both natural and WWTP-related communities of ammonia and nitrite oxidizing communities and use our kinetic parameters for each nitrifying community to parameterize the model. The best approach is to (1) sample the river water upstream of the main WWTP and the WWTP effluent, and (2) apply our methodology to evaluate biomasses and kinetic parameters of the nitrifying communities present in the specific system. Applying our approach, and not only our parameters, is especially necessary in systems receiving effluents from WWTPs with other technologies used for nitrogen removal.

\subsection{Nitrogen cycling in human impacted river systems: example of the Seine River}

The strength of distributed process-based modelling tools is to represent the fate of variables and fluxes linked to the various simulated biogeochemical processes, which are difficult to quantify through direct methods (e.g. in situ ammonia and nitrite oxidation rates, nitrifying biomasses). The ProSe model was used here to assess nitrifier biomasses along a $220 \mathrm{~km}$ stretch and to quantify the fluxes linked to the biogeochemical transformations of $\mathrm{NH}_{4}^{+}, \mathrm{NO}_{2}^{-}$, and $\mathrm{NO}_{3}^{-}$at a pluri-annual time scale.

\subsubsection{Effect of WWTP effluents on in-river nitrifying biomasses}

Our results confirm that effluents of advanced WWTP constitute a significant source of nitrifier biomass to river ecosystems (16-76 \%, this study). Our approach allows the study of biomass evolution for the two distinct nitrifying communities (river and WWTP) along the river. For the 2007-2012 period, the nitrifying biomass (whatever its origin and specificity) was stable during its transit towards the estuary at high water conditions (Fig. 6a), indicating that nitrifying biomass was mostly transported downstream, without noteworthy net growth. At low water conditions, the biomass of nitrifiers flowing from the WWTP increased (Fig. 6b), as already observed before 2007 when ammonium concentrations promoted nitrifier growth (Servais et al., 1999b; Brion and Billen, 1998; Cébron et al., 2003). The amplitude of ammonia 
oxidizer growth downstream the WWTP was however lower than before 2007 due to the lower in-stream ammonia concentrations since the addition of nitrification-denitrification units in SAV WWTP in 2007. These results highlight the feedback of the decrease of ammonia release by WWTPs on nitrifying communities/biomass in river systems.

Our results also show differences in biomass evolution along the river stretch between WWTP and river nitrifiers. While WWTP nitrifier biomass increased at low water conditions, the biomass of river nitrifiers tended to decrease. This is related to the higher affinity of WWTP nitrifiers for nitrite compared to nitrifiers initially present in the river. This indicates that studying nitrifier kinetics in river waters and WWTP effluents, and the survival of the different communities in the system (Féray and Montuelle, 2002), is needed to understand the evolution of nitrite in river systems. The evolution of nitrifier biomass along the river depends thus on point sources (i.e. WWTP), ecosystem hydrology (i.e. high or low river discharge), environmental conditions (e.g. ammonia and nitrite concentrations), and nitrifier activity (related to biomass and kinetics).

The explicit representation of nitrifying biomass for autochtonous and WWTP communities allows the simulation of the growth of both communities and their relative impact on river water quality.

\subsubsection{Persistence of nitrite in the water column downstream WWTP effluents}

The longitudinal profile of nitrite concentrations shows strong spatial variations, especially downstream main singularities (tributaries and effluents, see Fig. 5). The dilution of nitrite by the Oise River (70 km downstream of Paris) significantly reduces $\mathrm{NO}_{2}^{-}$concentrations in the system. This shows that accounting for the main tributaries is essential for a good representation of river biogeochemistry. The longitudinal profile also displays that nitrite is mostly produced just downstream the WWTP effluent, before it is slowly consumed by increasing nitrite oxidizers towards the estuary. WWTP-related nitrite oxidizing communities, which are efficient in the presence of riverine nitrite concentrations, take part in this consumption. However, the nitrite brought by the SAV effluent and produced downstream the WWTP is not totally consumed before the entrance of the estuary. $\mathrm{NO}_{2}^{-}$concentrations still reach values corresponding to a poor ecological status as defined by the European Water Framework Directive (Fig. 5). 
The quantification of daily averaged biogeochemical fluxes (for the whole 2007-2012 period) in the water column, in the unconsolidated sediments, and at the sediment-water interface enables us to explain the longitudinal evolution of in-river concentrations up- and downstream the SAV WWTP, for low and higher river discharge conditions (Fig. 7). The persistence of nitrite downstream the WWTP is mostly explained by the net production of nitrite in the water column which is $80 \%$ higher downstream than upstream the WWTP during low river discharge, and more than 7 times higher during high river discharge. This high net production downstream the WWTP is notably due to the high $\mathrm{NH}_{4}^{+}$levels in the water column. Nitrite consumption rates are also higher downstream the WWTP, so that nitrification processes are closer to equilibrium (same $\mathrm{NH}_{4}^{+}$and $\mathrm{NO}_{2}^{-}$oxidation rates) than upstream SAV WWTP. The ratio of $\mathrm{NO}_{2}^{-}$oxidation rate per $\mathrm{NH}_{4}^{+}$oxidation rate is in fact much lower downstream SAV WWTP (1.2 and 2.8 for low and high river discharge, respectively) than upstream SAV WWTP (over 17 for both low and high discharge conditions). This is due to the fact that WWTP nitrifiers were more abundant and efficient for nitrite oxidation (i.e. low $\mathrm{K}_{\mathrm{NO}_{2}^{-}}$) compared to the autochtonous ones. These results highlight the importance of nitrifiers released by WWTP effluents in nitrite production and consumption in the water column downstream WWTPs.

\subsubsection{Importance of benthic processes in nitrogen cycling and nitrite export to estuaries}

Nitrogen cycling is directly controlled by biotic processes (mineralization, denitrification, nitrification, and uptake by phytoplankton), and indirectly by hydro-sedimentary processes. Accumulation of particles (notably organic matter, heterotrophic and nitrifying micro-organisms) on the river bed, and their re-suspension, determine the intensity of benthic processes and of exchanges at the sediment-water interface. Hydro-sedimentary processes were calibrated and validated by Vilmin et al. (2015), which allows an estimation of sediment accumulation in the river bed and of the intensity of benthic biogeochemical processes and sediment-water exchanges.

Inorganic nitrogen in the water column is largely dominated by $\mathrm{NO}_{3}^{-}$(88-97\%) (Fig. 7). Nitrate concentrations are mainly driven by the fluxes flowing from the upper agricultural drainage basin to the river system (Garnier et al., 2006; Polus et al., 2011) and, to a lesser extent, by anthropogenic effluents. Given the large amount of $\mathrm{NO}_{3}^{-}$in the water column, the fluxes linked to in-river biogeochemical processes have very little effect on the $\mathrm{NO}_{3}^{-}$fluxes 
exported at the estuary. In fact, these in-river processes (in the water column and in the sediment layer) contribute to less than $1 \%$ of the increase of $\mathrm{NO}_{3}^{-}$fluxes between the Paris urban area and the estuary.

$\mathrm{NH}_{4}^{+}$concentrations are not only affected by nitrification processes, but also by the mineralization of organic matter and uptake by phytoplankton. At high discharge conditions, $\mathrm{NH}_{4}^{+}$ is produced in the river system both up- and downstream the SAV WWTP (Fig. 7). At low discharge conditions downstream SAV, the river system constitutes a significant sink of ammonium, and therefore contributes to the Seine River self-purification. 7.5 tons of $\mathrm{N}$ of $\mathrm{NH}_{4}^{+}$are consumed per day, while 2.0 tons are produced by mineralization of organic matter, along this $142 \mathrm{~km}$ stretch. $25 \%$ of this total consumption $\left(7.5\right.$ tons of $\mathrm{N}$ ) is due to $\mathrm{NH}_{4}^{+}$consumption in the benthic layer.

The Seine River usually constitutes a source of nitrite, with a higher nitrite production than consumption (Fig. 7). Part of this nitrite is produced in river bed sediments $(0.025-0.244$ TN $d^{-1}$ ) and transferred to the water column by diffusion (Morris et al., 1985; Kelso et al., 1997), except downstream the WWTP at low river discharge conditions $\left(-0.01 \mathrm{TN} d^{-1}\right)$, when more $\mathrm{NO}_{2}^{-}$is consumed than produced in the benthic layer. At low river discharge conditions upstream the WWTP, a large part of the $\mathrm{NO}_{2}^{-}$produced in the water column (up to $30 \%$, this study) originates from the benthic nitrifying activity. The impact of benthic sediments is also significant during high discharge conditions, when one fifth of the $\mathrm{NO}_{2}^{-}$produced in the water column originates from the unconsolidated sediment layer. Even though the contact time between the water and the sediment layer is smaller in high discharge conditions, the sediment layer has a significant effect on nitrite fluxes. This is explained by the imbalance between nitrite production and consumption in the sediment layer during high discharge conditons. As a result of point sources and in-stream biogeochemical processes, the river is a source of nitrite to the estuary (means of 4.1 and $5.6 \mathrm{TN} d^{-1}$ in low and high river discharge, respectively).

Our results point out the importance of taking biological activity in benthic sediments into account. In fact, a large proportion of in-river nitrification takes place in this sediment layer; the produced nitrite is then transferred to the water column by diffusion and transport (erosion, bioturbation/bioirrigation). Even if sediments are known to have less impact on nitrogen cycling i.e. nitrate dynamics in large river systems with low surface-to-volume ratios (Pinay 
et al., 2002), their effect on nitrite export at estuaries is definitely significant. Considering the importance of benthic sediments in nitrite dynamics (this study), the role of benthic anaerobic nitrate reduction (denitrification, DNRA), and their coupling with nitrification, in riverine nitrite dynamics must be evaluated through an approach similar to the one developped for nitrifiers in this study.

\subsection{Assessment and management of nitrite in rivers}

Accounting for distinct biomasses and kinetic parameters of nitrifying communities in the river and in point source effluents (i.e. WWTP) allowed a proper modelling of concentrations and dynamics of nitrite in the Seine River. The quantification of biomass and kinetic parameters of ammonia and nitrite oxidizers is thus essential to parameterize nitrifying communities in hydro-ecological models in anthropized rivers. Once the model provides reliable results compared to monitoring data, it can be used to complete our understanding of the ecological functioning of the system or to support monitoring and management strategies (Poulin et al., 1998; Rode et al., 2010; Bende-Michl et al., 2011).

Compared to local sampling, models allow the simulation of the water quality of river systems at extremely small spatio-temporal resolution, over a large spatio-temporal extent and for a large number of variables and fluxes. One model output is the annual $90 \%$ quantile of $\mathrm{NH}_{4}^{+}, \mathrm{NO}_{2}^{-}$, and $\mathrm{NO}_{3}^{-}$concentrations which is, according to the European Water Framework Directive, the statistical criterion used to assess the water quality status accounting for transient nutrient concentration peaks. The model allows to access the high spatial variability of water quality criteria, which is not always captured by local sampling (Polus et al., 2010).

As monitoring is an expensive task in water quality assessment, sampling strategies need to be optimized (Nadeo et al., 2013). Model outputs are efficient to determine the minimum sampling time step necessary to estimate water quality levels. Our results suggest that monthly sampling is enough for the assessment of nitrate dynamics, and the assessment of the water quality level regarding nitrate concentrations. The variability of nitrate is mostly explained by diffusive fluxes due to agricultural practices. On the contrary, monthly sampling is not sufficient to capture ammonia and nitrite concentration peaks, and leads to the over- or underestimation of the annual $90 \%$ ammonia and nitrite concentration quantiles compared to averaged highfrequency model outputs. Weekly sampling at least is required to calculate accurate quality 
criteria accounting for the high variability of ammonia (along the whole river) and nitrite (after WWTP effluent). The optimal sampling frequency depends on sampling location (hydromorphological characteristics, presence of anthropogenic loads), and indicator variability in the receiving environment (Lázslo et al., 2007). Hydro-ecological models validated at fine spatiotemporal scales, as the PROSE model, can be usefully coupled with monitoring surveys in order to avoid expensive high frequency sampling and improve the assessment of water quality levels regarding highly variable substances as $\mathrm{NH}_{4}^{+}$and $\mathrm{NO}_{2}^{-}$. As river ecosystems are submitted to variable natural and most often anthropogenic forcings, adaptability of monitoring frequency is required if changes in nutrient variability are generated by modified loads.

The validated model can also be employed to assess the impact of future management strategies or the implementation of new waste water treatment technologies (Even et al., 2007a; Kannel et al., 2007; Richter et al., 2013). For instance, we evaluated the effect of the implementation of micro-filtration, chlorine or ultraviolet radiation at the outlet of nitrification/denitrification units, i.e. suppression of microorganisms, on nitrite dynamics in the river. The results show that the implementation of such a filtration system in the WWTP would lead to an increase of nitrite concentrations downstream the WWTP towards the estuary. This result underlines the importance of maintaining in the effluent ammonia and nitrite oxidizer communities, which increases the nitrifying activity and eliminates part of the ammonium and nitrite discharged and produced in the river system. The method proposed in this paper can be applied to investigate the effect of diverse human perturbations on nitrogen cycling in any river system.

\section{Conclusions}

A cost efficient method is proposed here to study the nitrogen cycling (including nitrite dynamics) in anthropogenic rivers subject to nitrite contamination. Accounting for distinct communities of ammonia oxidizers and nitrite oxidizers in river water and WWTP effluents in the river, and quantifying their biomasses and kinetics, leads to an accurate simulation of nitrite concentrations downstream WWTP effluents and allows the assessment of each community distribution along the river. The representation of benthic processes is essential for an correct simulation of nitrite dynamics and fluxes in large urbanized rivers. In the case of the Seine River downstream the Paris urban area, benthic nitrite production constitutes for example one fifth of the total nitrite flux exported to the estuary at high flow conditions. Our results point out 
how essential the coupling of monitoring and modelling tools is to improve our understanding of in-river biogeochemical cycles, to improve the assessment of the quality of aquatic systems, and to decrease water quality management costs. Besides the additional information that models can provide to in situ measurements on ecosystem functioning, models can be used to forecast the impact of possible future management strategies.

\section{Acknowledgements}

This study was funded by R2DS and PIREN-Seine programs. We gratefully thank Julien Pouillaude, Erwan Garcia-Gonzalez, Céline Briand, Sabrina Guérin from the Syndicat Interdépartemental pour l'Assainissement de l'Agglomération Parisienne (SIAAP) for helping in water sampling, Laura Culoma, Laurence Millot, Céline Roose-Amsaleg, Arnaud Blanchouin, Adrienne Jonnet, Bruno Monteiro, Lucas Gandy for assistance in the laboratory.

\section{References}

Andersson, M. G. I., Brion, N., Middelburg, J. J., 2006. Comparison of nitrifier activity versus growth in the Scheldt estuary - a turbid, tidal estuary in northern Europe. Aquatic Microbial Ecology 42, 149-158.

Arheimer, B., Olsson, J., 2003. Integration and coupling of hydrological models with water quality models: Applications in Europe. Tech. rep., Workgroup Report, WMO RA VI (K55.1.02).

Belser, L. W., 1979. Population Ecology of Nitrifying Bacteria. Annual Review of Microbiology 33 (1), 309-333.

Bende-Michl, U., Volk, M., Harmel, D., Newham, L., Dalgaard, T., 2011. Monitoring strategies and scale appropriate hydrologic and biogeochemical modelling for natural resource management: Conclusions and recommendations from a session held at the iEMSs 2008 . Environmental Modelling \& Software 26, 538-542.

Billen, G., Garnier, J., Hanset, P., 1994. Modelling phytoplankton development in whole drainage networks: The RIVERSTRAHLER model applied to the Seine river system. Hydrobiologia 289, 119-137. 
Blackburne, R., Vadivelu, V. M., Yuan, Z., Keller, J., 2007. Kinetic characterisation of an enriched Nitrospira culture with comparison to Nitrobacter. Water Research 41 (14), 30333042.

Boon, B., Laudelout, H., 1962. Kinetics of nitrite oxidation by Nitrobacter winogradskyi. Biochemical Journal 85 (3), 440-447.

Both, G. J., Gerards, S., Laanbroek, H. J., 1992. Kinetics of nitrite oxidation in two Nitrobacter species grown in nitrite-limited chemostats. Archives of Microbiology 157 (5), 436-441.

Brion, N., Billen, G., 1998. Une réévaluation de la methode d'incorporation de $\mathrm{H}^{14} \mathrm{CO}_{3}^{-}$pour mesurer la nitrification autotrophe et son application pour estimer des biomasses de bactéries nitrifiantes. Revue des sciences de l'eau 11 (2), 283-302.

Brion, N., Billen, G., Guzennec, L., Ficht, A., 2000. Distribution of nitrifying activity in the Seine River (France) from Paris to the estuary. Estuaries and Coasts 23 (5), 669-682.

Canavan, R. W., Slomp, C. P., Jourabchi, P., Van Cappellen, P., Laverman, A. M., van den Berg, G. A., Jun. 2006. Organic matter mineralization in sediment of a coastal freshwater lake and response to salinization. Geochimica et Cosmochimica Acta 70 (11), 2836-2855, 00059.

Carey, R. O., Migliaccio, K. W., 2009. Contribution of Wastewater Treatment Plant Effluents to Nutrient Dynamics in Aquatic Systems: A Review. Environmental Management 44 (2), 205-217.

Cébron, A., Berthe, T., Garnier, J., 2003. Nitrification and Nitrifying Bacteria in the Lower Seine River and Estuary (France). Applied and Environmental Microbiology 69 (12), 70917100.

Cébron, A., Garnier, J., 2005. Nitrobacter and Nitrospira genera as representatives of nitriteoxidizing bacteria: Detection, quantification and growth along the lower Seine River (France). Water Research 39 (20), 49794992.

Cébron, A., Garnier, J., Billen, G., 2005. Nitrous oxide production and nitrification kinetics by 
natural bacterial communities of the lower Seine river (France). Aquatic Microbial Ecology $41,25-38$.

Corriveau, J., van Bochove, E., Savard, M. M., Cluis, D., Paradis, D., 2010. Occurrence of High In-Stream Nitrite Levels in a Temperate Region Agricultural Watershed. Water, Air, and Soil Pollution 206 (1-4), 335-347.

Cox, B. A., 2003. A review of currently available in-stream water-quality models and their applicability for simulating dissolved oxygen in lowland rivers. Sci. Total Environ. 314-316, $335-377$.

Drtil, M., Németh, P., Bodk, I., 1993. Kinetic constants of nitrification. Water Research 27 (1), $35-39$.

Even, S., Bacq, N., Ruelland, D., Billen, G., Garnier, J., Poulin, M., Théry, S., Blanc, S., 2007a. New tools for modelling water quality of hydrosystems: An application in the Seine River basin in the frame of the Water Framework Directive. Sci. Total Environ. 375 (1-3), $274-291$.

Even, S., Mouchel, J.-M., Servais, P., Flipo, N., Poulin, M., Blanc, S., Chabanel, M., Paffoni, C., 2007b. Modeling the impacts of Combined Sewer Overflows on the river Seine water quality. Sci. Total Environ. 375 (1-3), 140-151.

Even, S., Poulin, M., Garnier, J., Billen, G., Servais, P., Chesterikoff, A., Coste, M., 1998. River ecosystem modelling: Application of the PROSE model to the Seine river (France). Hydrobiologia 373, 27-37.

Even, S., Poulin, M., Mouchel, J.-M., Seidl, M., Servais, P., 2004. Modelling oxygen deficits in the Seine river downstream of combined sewer overflows. Ecol. Model. 173, 177-196.

Even, S., Thouvenin, B., Bacq, N., Billen, G., Garnier, J., Guézennec, L., Blanc, S., Ficht, A., Hir, P. L., 2007c. An integrated modelling approach to forecast the impact of human pressure in the Seine estuary. Hydrobiologia 588 (1), 13-29.

Féray, C., Montuelle, B., 2002. Competition between two nitrite-oxidizing bacterial populations: 
a model for studying the impact of wastewater treatment plant discharge on nitrification in sediment. FEMS Microbiology Ecology 42 (1), 15-23.

Flipo, N., Even, S., Poulin, M., Tusseau-Vuillemin, M.-H., Améziane, T., Dauta, A., 2004. Biogeochemical modelling at the river scale: Plankton and periphyton dynamics - Grand Morin case study, France. Ecol. Model. 176, 333-347.

Flipo, N., Rabouille, C., Poulin, M., Even, S., Tusseau-Vuillemin, M., Lalande, M., 2007. Primary production in headwater streams of the Seine basin: the Grand Morin case study. Sci. Total Environ. 375, 98-109.

García-Barcina, J. M., González-Oreja, J. A., De la Sota, A., 2006. Assessing the improvement of the Bilbao estuary water quality in response to pollution abatement measures. Water Research 40 (5), 951-960.

Garnier, J., Billen, G., Cébron, A., 2007. Modelling nitrogen transformations in the lower Seine river and estuary (France): impact of wastewater release on oxygenation and N2O emission. Hydrobiologia 588 (1), 291-302.

Garnier, J., Billen, G., Coste, M., 1995. Seasonal succession of diatoms and chlorophycae in the drainage network of the river Seine: Observations and modelling. Limnol. Oceanogr. 40 (4), $750-765$.

Garnier, J., Cébron, A., Tallec, G., Billen, G., Sebilo, M., Martinez, A., 2006. Nitrogen Behaviour and Nitrous Oxide Emission in the Tidal Seine River Estuary (France) as Influenced by Human Activities in the Upstream Watershed. Biogeochemistry 77 (3), 305-326.

Goñi Urriza, M., Capdepuy, M., Arpin, C., Raymond, N., Caumette, P., Quentin, C., Jan. 2000. Impact of an urban effluent on antibiotic resistance of riverine Enterobacteriaceae and Aeromonas spp. Applied and Environmental Microbiology 66 (1), 125-132, 00304 PMID: 10618213.

Gould, G. W., Lees, H., 1960. The Isolation and Culture of the Nitrifying Organisms: Part I. Nitrobacter. Canadian Journal of Microbiology 6 (3), 299-307. 
Helder, W., De Vries, R. T. P., 1983. Estuarine nitrite maxima and nitrifying bacteria (EmsDollard estuary). Netherlands Journal of Sea Research 17 (1), 1-18.

Henriksen, K., Kemp, W. M., 1988. Nitrification in estuarine and coastal marine sediments. In: Nitrogen cycling in coastal marine sediments. T. H. Blackburn and J. Srensen, pp. 201-249.

Jiménez, E., Giménez, J. B., Ruano, M. V., Ferrer, J., Serralta, J., 2011. Effect of pH and nitrite concentration on nitrite oxidation rate. Bioresource Technology 102 (19), 8741-8747.

Kannel, P. R., Kanel, S. R., Lee, S., Lee, Y.-S., Gan, T. Y., 2011. A review of Public Domain Water Quality Models for Simulating Dissolved Oxygen in Rivers and Streams. Environ Model Assess 16, 183-204.

Kannel, P. R., Lee, S., Lee, Y.-S., Kanel, S. R., Pelletier, G. J., 2007. Application of automated QUAL2Kw for water quality modeling and management in the Bagmati River, Nepal. Ecol. Model. 202, 503-517.

Kelso, B., Smith, R. V., Laughlin, R. J., Lennox, S. D., 1997. Dissimilatory nitrate reduction in anaerobic sediments leading to river nitrite accumulation. Applied and Environmental Microbiology 63 (12), 4679-4685.

Knobeloch, L., Salna, B., Hogan, A., Postle, J., Anderson, H., 2000. Blue babies and nitratecontaminated well water. Environ Health Perspect 108 (7), 675-678.

Knowles, G., Downing, A. L., Barrett, M. J., 1965. Determination of Kinetic Constants for Nitrifying Bacteria in Mixed Culture, with the Aid of an Electronic Computer. Journal of General Microbiology 38 (2), 263-278.

Kowalchuk, G. A., Stephen, J. R., 2001. Ammonia-oxidizing bacteria : A model for molecular microbial ecology. Annual review of microbiology 55, 485-529.

Lázslo, B., Szilágyi, E., Heltai, G., Licskó, I., 2007. Implementation of the EU Water Framework Directive in monitoring of small water bodies in Hungary, I. Establishment of surveillance monitoring system for physical and chemical characteristics for small mountain watercourses. Microchemical Journal 85, 65-71. 
Martens-Habbena, W., Berube, P. M., Urakawa, H., de la Torre, J. R., Stahl, D. A., 2009. Ammonia oxidation kinetics determine niche separation of nitrifying Archaea and Bacteria. Nature 461 (7266), 976-979.

Meybeck, M., 1982. Carbon, nitrogen, and phosphorus transport by world rivers. Am J Sci $282(4), 401-450$.

Morris, A. W., Howland, R. J. M., Woodward, E. M. S., Bale, A. J., Mantoura, R. F. C., 1985. Nitrite and ammonia in the Tamar estuary. Netherlands Journal of Sea Research 19 (34), $217-222$

Nadeo, V., Scannapecio, D., Zarra, T., Belgiorno, V., 2013. River water quality assessment: Implementation of non-parametric tests for sampling frequency optimization. Land Use Policy $30,197-205$.

Park, S., Bae, W., 2009. Modeling kinetics of ammonium oxidation and nitrite oxidation under simultaneous inhibition by free ammonia and free nitrous acid. Process Biochemistry 44 (6), $631-640$.

Philips, S., Laanbroek, H. J., Verstraete, W., 2002. Origin, causes and effects of increased nitrite concentrations in aquatic environments. Reviews in Environmental Science and Biotechnology 1 (2), 115-141.

Pinay, G., Clément, J.-C., Naiman, R. J., 2002. Basic principles and ecological consequences of changing water regimes on nitrogen cycling in fluvial systems. Environmental Management $30(4), 481-491$.

Polus, E., de Fouquet, C., Flipo, N., Poulin, M., 2010. Spatial and temporal caracterization of "river water bodies". Revue des Sciences de l'Eau / Journal of Water Science 23 (4), 415-429.

Polus, E., Flipo, N., de Fouquet, C., Poulin, M., 2011. Geostatistics for assessing the efficiency of distributed physically-based water quality model. Application to nitrates in the Seine River. Hydrological Processes 25 (2), 217-233.

Poulin, M., Even, S., Billen, G., Mouchel, J.-M., Garnier, J., Levassor, A., Leviandier, T., 1998. 
La Seine en son bassin. Fonctionnement écologique d'un système fluvial anthropisé. Elsevier, Ch. Modèles : des processus au bassin versant, pp. 679-720.

Rauch, W., Henze, M., Koncsocs, L., Reichert, P., Shanahan, P., Somlyody, L., Vanrolleghem, P., 1998. River water quality modelling: I. state of the art. Water Science and Technology 38 (11), 237-244.

Reichert, P., 2001. River Water Quality Model no.1 (RWQM1) : Case study II oxygen and nitrogen conversion processes in the river glatt (Switzerland). Water Science and Technology $43(5), 51-60$.

Richter, S., Völker, J., Borchardt, D., Mohaupt, V., 2013. The Water Framework Directive as an approach for Integrated Water Resources Management: results from the experiences in Germany on implementation, and future perspectives. Environ. Earth. Sci. 69, 719-728.

Rocher, V., Garcia-Gonzalez, E., Paffoni, C., Thomas, W., 2011. La production de nitrites lors de la dénitrification des eaux usées: un sujet sensible et complexe ! L' Eau, l'industrie, les nuisances $344,80-83$.

Rode, M., Arhonditsis, G., Balin, D., Kebede, T., Krysanova, V., van Griensven, A., van der Zee, S., 2010. New challenges in integrated water quality modelling. Hydrological Processes $24,3447-3461$.

Rodier, J., 1984. L'analyse de l'eau (eaux naturelles, eaux résiduaires, eau de mer), Dunod Edition. Paris.

Röling, W. F. M., 2007. Do microbial numbers count? quantifying the regulation of biogeochemical fluxes by population size and cellular activity. FEMS Microbiology Ecology 62 (2), 202-210.

Schmidt, I., Sliekers, O., Schmid, M., Bock, E., Fuerst, J., Kuenen, J. G., Jetten, M. S. M., Strous, M., 2003. New concepts of microbial treatment processes for the nitrogen removal in wastewater. FEMS Microbiology Reviews 27 (4), 481-492.

Servais, P., Garnier, J., Demarteau, N., Brion, N., Billen, G., 1999a. Supply of organic matter 
and bacteria to aquatic ecosystems through waste water effluents. Water Research 33 (16), $3521-3531$.

Servais, P., Garnier, J., Demarteau, N., Brion, N., Billen, G., 1999b. Supply of organic matter and bacteria to aquatic ecosystems through waste water effluents. Water Research 33, 35213531.

Sharma, D., Kansal, A., 2013. Assessment of river quality models: a review. Reviews in Environmental Science and Bio/Technology 12, 285-311.

Tappe, W., Laverman, A., Bohland, M., Braster, M., Rittershaus, S., Groeneweg, J., Verseveld, V., W, H., Jan. 1999. Maintenance Energy Demand and Starvation Recovery Dynamics of Nitrosomonas Europaea and Nitrobacter Winogradskyi Cultivated in a Retentostat with Complete Biomass Retention. Applied and Environmental Microbiology 65 (6), 2471-2477.

Vilmin, L., Aissa-Grouz, N., Garnier, J., Billen, G., Mouchel, J.-M., Poulin, M., Flipo, N., in press. Impact of hydro-sedimentary processes on the dynamics of soluble reactive phosphorus in the Seine River. Biogeochemistry, 1-23.

Vilmin, L., Flipo, N., de Fouquet, C., Poulin, M., 2015. Pluri-annual sediment budget in a navigated river sytem: the Seine River (France). Sci. Total Environ. 502, 48-59.

Vilmin, L., Flipo, N., Poulin, M., 2012. Le modèle de simulation biogéochimique C-RIVE. Tech. rep., PIREN Seine.

von der Wiesche, M., Wetzel, A., 1998. Temporal and spatial dynamics of nitrite accumulation in the River Lahn. Water Research 32 (5), 1653-1661.

Wiesmann, U., 1994. Biological nitrogen removal from wastewater. In: Biotechnics/Wastewater. No. 51 in Advances in Biochemical Engineering/Biotechnology. Springer Berlin Heidelberg, pp. 113-154.

Wilderer, P. A., Jones, W. L., Dau, U., 1987. Competition in denitrification systems affecting reduction rate and accumulation of nitrite. Water Research 21 (2), 239-245.

Tables 
Table 1: Variables and parameters used in C-RIVE. Fixed values, screened ranges and optimal values of parameters for river and WWTP samples are given.

\begin{tabular}{|c|c|c|c|c|c|}
\hline & & \multirow[t]{2}{*}{ Unit } & \multirow{2}{*}{$\begin{array}{l}\text { Fixed values or } \\
\text { screened ranges }\end{array}$} & \multicolumn{2}{|c|}{ Optimal values } \\
\hline & & & & River & WWTP \\
\hline $\begin{array}{l}\mathrm{NH}_{4}^{+} \\
\mathrm{NO}_{2}^{-} \\
\mathrm{NO}_{3}^{-} \\
\mathrm{O}_{2} \\
\mathrm{BN}_{\mathrm{AO}} \\
\mathrm{BN}_{\mathrm{NO}}\end{array}$ & $\begin{array}{l}\text { Variables } \\
\text { Ammonium concentration } \\
\text { Nitrite concentration } \\
\text { Nitrate concentration } \\
\text { Dissolved oxygen concentration } \\
\text { Ammonia oxidizer biomass } \\
\text { Nitrite oxidizer biomass }\end{array}$ & $\begin{array}{l}{\left[\mathrm{mgN} \mathrm{L}^{-1}\right]} \\
{\left[\mathrm{mgN} \mathrm{L}^{-1}\right]} \\
{\left[\mathrm{mgN} \mathrm{L}^{-1}\right]} \\
{\left[\mathrm{mgO}_{2} \mathrm{~L}^{-1}\right]} \\
{\left[\mathrm{mgC} \mathrm{L}^{-1}\right]} \\
{\left[\mathrm{mgC} \mathrm{L}^{-1}\right]}\end{array}$ & $\begin{array}{l}{[0.0001-0.03]} \\
{[0.0005-0.03]}\end{array}$ & $\begin{array}{c}0.0075 \\
0.001\end{array}$ & $\begin{array}{l}0.027 \\
0.008\end{array}$ \\
\hline $\begin{array}{l}T_{\mathrm{opt}, A O} \\
\sigma_{A O} \\
\text { mort }_{A O} \\
Y_{A O} \\
K_{O_{2}, A O} \\
r_{O_{2}, A O} \\
V_{\text {sed }, A O} \\
h \\
\mu_{\max , A O}^{*} \\
K_{N H_{4}^{+}}\end{array}$ & $\begin{array}{l}\quad \text { Ammonia oxidizer parameters } \\
\text { Optimal temperature } \\
\text { Standard-deviation of the temperature function } \\
\text { Mortality rate } \\
\text { Nitrification yield } \\
\text { Half-saturation constant for oxygen } \\
\text { Mol of } \mathrm{O}_{2} \text { consumed for } 1 \mathrm{~mol} \text { of } \mathrm{NH}_{4}^{+} \text {oxidized } \\
\text { Sedimentation rate } \\
\text { Water depth } \\
\text { Maximal growth rate } \\
\text { Half-saturation constant for ammonium }\end{array}$ & $\begin{array}{l}{\left[{ }^{\circ} \mathrm{C}\right]} \\
{\left[{ }^{\circ} \mathrm{C}\right]} \\
{\left[\mathrm{h}^{-1}\right]} \\
\left.\mathrm{molC}(\mathrm{molN})^{-1}\right] \\
{\left[\mathrm{mgO}_{2} \mathrm{~L}^{-1}\right]} \\
{[]} \\
{\left[\mathrm{m} \mathrm{h}^{-1}\right]} \\
{\left[\mathrm{m}^{-1}\right.} \\
{\left[\mathrm{h}^{-1}\right]} \\
{\left[\mathrm{mgN} \mathrm{L}^{-1}\right]}\end{array}$ & $\begin{array}{l}23 \\
12 \\
0.01 \\
0.09 \\
0.5 \\
1.5 \\
0.1 \\
{[0.01-0.2]} \\
{[0.1-20]}\end{array}$ & $\begin{array}{c}0.04 \\
2\end{array}$ & $\begin{array}{c}0.05 \\
1.5\end{array}$ \\
\hline $\begin{array}{l}T_{\mathrm{opt}, \mathrm{NO}} \\
\sigma_{\mathrm{NO}} \\
\text { mort }_{\mathrm{NO}} \\
Y_{\mathrm{NO}} \\
K_{\mathrm{O}_{2}, \mathrm{NO}} \\
r_{\mathrm{O}_{2}, \mathrm{NO}} \\
V_{\text {sed }, \mathrm{NO}} \\
\mu_{\max , \mathrm{NO}}^{*} \\
K_{\mathrm{NO}_{2}^{-}}\end{array}$ & $\begin{array}{l}\quad \text { Nitrite oxidizer parameters } \\
\text { Optimal temperature } \\
\text { Standard-deviation of the temperature function } \\
\text { Mortality rate } \\
\text { Nitrification yield } \\
\text { Half-saturation constant for oxygen } \\
\text { Mol of } \mathrm{O}_{2} \text { consumed for } 1 \text { mol of } \mathrm{NO}_{2}^{-} \text {oxidized } \\
\text { Sedimentation rate } \\
\text { Maximal growth rate } \\
\text { Half-saturation constant for nitrite }\end{array}$ & $\begin{array}{l}{\left[{ }^{\circ} \mathrm{C}\right]} \\
{\left[{ }^{\circ} \mathrm{C}\right]} \\
{\left[\mathrm{h}^{-1}\right]} \\
\left.\left[\mathrm{molC}^{-1} \mathrm{molN}\right)^{-1}\right] \\
{\left[\mathrm{mgO}_{2} \mathrm{~L}^{-1}\right]} \\
{[]} \\
{\left[\mathrm{m} \mathrm{h}^{-1}\right]} \\
{\left[\mathrm{h}^{-1}\right]} \\
{\left[\mathrm{mgN} \mathrm{L}^{-1}\right]}\end{array}$ & $\begin{array}{l}23 \\
12 \\
0.01 \\
0.026 \\
1.1 \\
0.5 \\
0.1 \\
{[0.01-0.2]} \\
{[0.1-20]}\end{array}$ & $\begin{array}{c}0.07 \\
10\end{array}$ & $\begin{array}{c}0.04 \\
0.3\end{array}$ \\
\hline
\end{tabular}


Table 2: Synthesis of kinetic parameters and biomasses of ammonia oxidizers in environmental waters and bacterial cultures.

\begin{tabular}{|c|c|c|c|c|}
\hline $\begin{array}{l}\mu_{\max } \\
{\left[h^{-1}\right]}\end{array}$ & $\begin{array}{l}K_{M} \\
{\left[m g N L^{-1}\right]}\end{array}$ & $\begin{array}{l}{[B N]} \\
{\left[m g C L^{-1}\right]}\end{array}$ & $\begin{array}{l}Y_{n i t} \\
{\left[m g C m g N^{-1}\right]}\end{array}$ & Reference \\
\hline \multicolumn{5}{|c|}{ Environmental microbial communities } \\
\hline 0.008-0.09 & $0.2-8$ & $0.00026-0.068$ & & Knowles et al. (1965) \\
\hline $0.028-0.05$ & $0.8-1.5$ & & $0.05-0.077$ & Cébron et al. (2005) \\
\hline \multicolumn{5}{|c|}{ Nitrosomonas cultures } \\
\hline 0.003 & & & & Schmidt et al. (2003) \\
\hline $0.014-0.065$ & & & & Blackburne et al. (2007) \\
\hline $0.032-0.05$ & $0.84-2.38$ & & $0.07-0.13$ & Brion and Billen (1998) \\
\hline 0.032 & 0.028 & & 0.147 & Wiesmann (1994) \\
\hline \multirow[t]{6}{*}{0.036} & $0.78-1.30$ & & & Helder and De Vries (1983) \\
\hline & 0.76 & & & Drtil et al. (1993) \\
\hline & $1.96-56$ & & & Belser (1979) \\
\hline & $11.1-74.2$ & & & Park and Bae (2009) \\
\hline & $0.98-9.8$ & & & Henriksen and Kemp (1988) \\
\hline & 0.002 & & & Martens-Habbena et al. (2009) \\
\hline
\end{tabular}

Table 3: Synthesis of kinetic parameters and biomasses of nitrite oxidizers in environmental waters and bacterial cultures.

\begin{tabular}{|c|c|c|c|c|}
\hline $\begin{array}{l}\mu_{\max } \\
{\left[h^{-1}\right]}\end{array}$ & $\begin{array}{l}K_{M} \\
{\left[m g N L^{-1}\right]}\end{array}$ & $\begin{array}{l}{[B N]} \\
{\left[m g C L^{-1}\right]}\end{array}$ & $\begin{array}{l}Y_{n i t} \\
{\left[m g C m g N^{-1}\right]}\end{array}$ & Reference \\
\hline \multicolumn{5}{|c|}{ Environmental microbial communities } \\
\hline $0.02-0.1$ & $0.18-8$ & 0.00004-0.06 & & Knowles et al. (1965) \\
\hline $0.051-0.064$ & $0.001-0.028$ & & $0.01-0.02$ & Cébron et al. (2005) \\
\hline \multicolumn{5}{|c|}{ Nitrobacter cultures } \\
\hline 0.04 & & & & Schmidt et al. (2003) \\
\hline $0.058\left(28^{\circ} \mathrm{C}\right)$ & & & & Gould and Lees (1960) \\
\hline $0.051-0.064$ & $0.001-0.028$ & & $0.014-0.024$ & Brion and Billen (1998) \\
\hline 0.045 & 0.000032 & & 0.042 & Wiesmann (1994) \\
\hline $0.005-0.6$ & $1.2-1.3$ & & & Blackburne et al. (2007) \\
\hline $0.058\left(32^{\circ} \mathrm{C}\right)$ & 22.4 & & & Boon and Laudelout (1962) \\
\hline 0.04 & $0.5-19.2$ & & & Both et al. (1992) \\
\hline 0.064 & $1.6-3.7$ & & & Helder and De Vries (1983) \\
\hline & $0.05-3$ & & & Jiménez et al. (2011) \\
\hline & $1.54-28$ & & & Park and Bae (2009) \\
\hline & $4.9-8.4$ & & & Henriksen and Kemp (1988) \\
\hline \multicolumn{5}{|c|}{ Nitrospira cultures } \\
\hline & $0.9-1.1$ & & & Blackburne et al. (2007) \\
\hline
\end{tabular}

Table 4: Statistical criteria (RMSE in $\mathrm{mgN} \mathrm{L}^{-1}$ ) for 6-year $\mathrm{NO}_{2}^{-}$time-series at the four monitoring stations shown in Fig.4. LW = low water conditions, $\mathrm{HW}=$ high water conditions.

\begin{tabular}{lccc}
\hline Station & LW & HW & $2007-2012$ \\
\hline Asnières & 0.019 & 0.015 & 0.017 \\
Sartrouville & 0.034 & 0.012 & 0.025 \\
Poissy & 0.089 & 0.035 & 0.067 \\
Poses & 0.184 & 0.057 & 0.141 \\
\hline
\end{tabular}




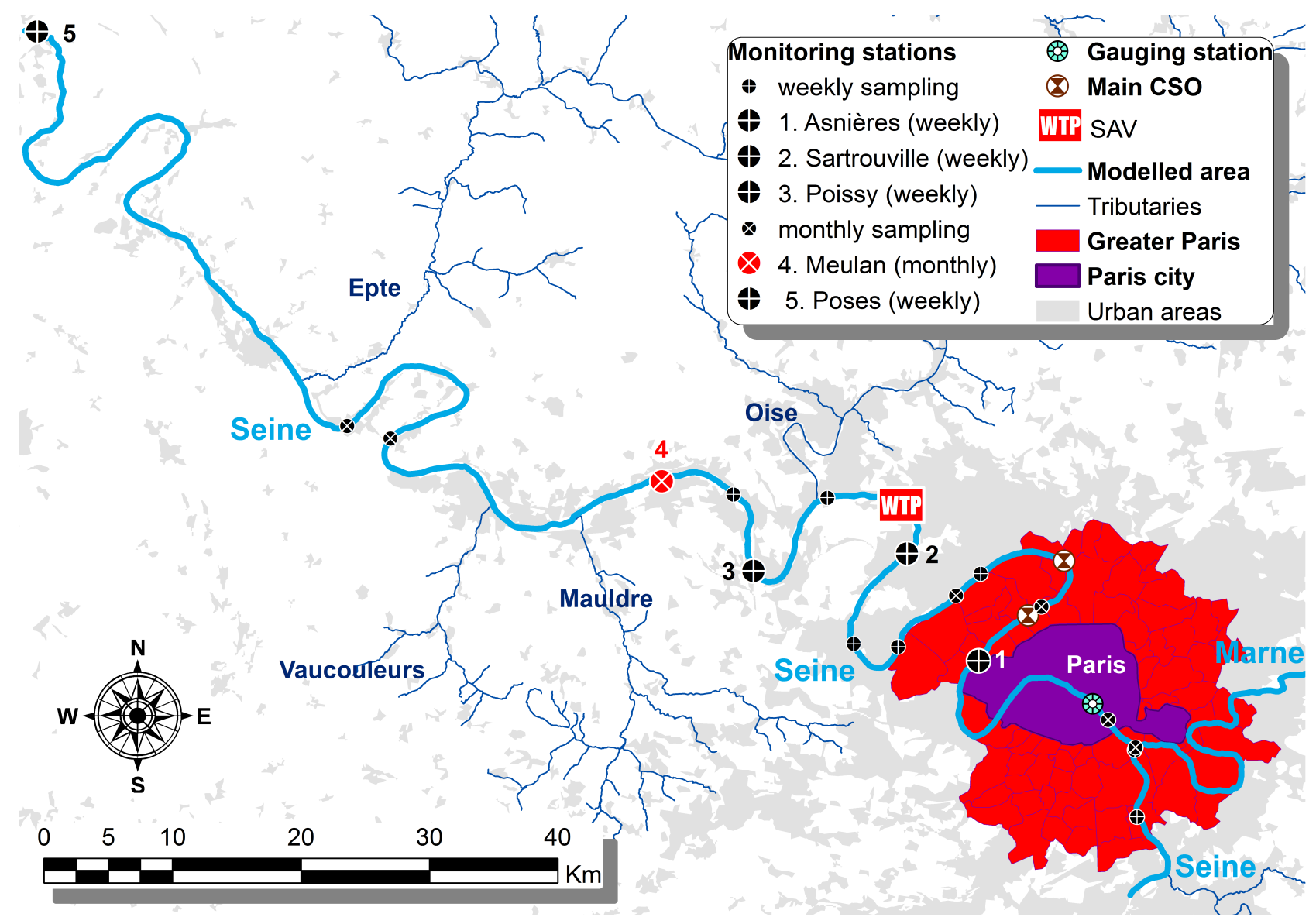

Figure 1: Study site and sampling stations. 


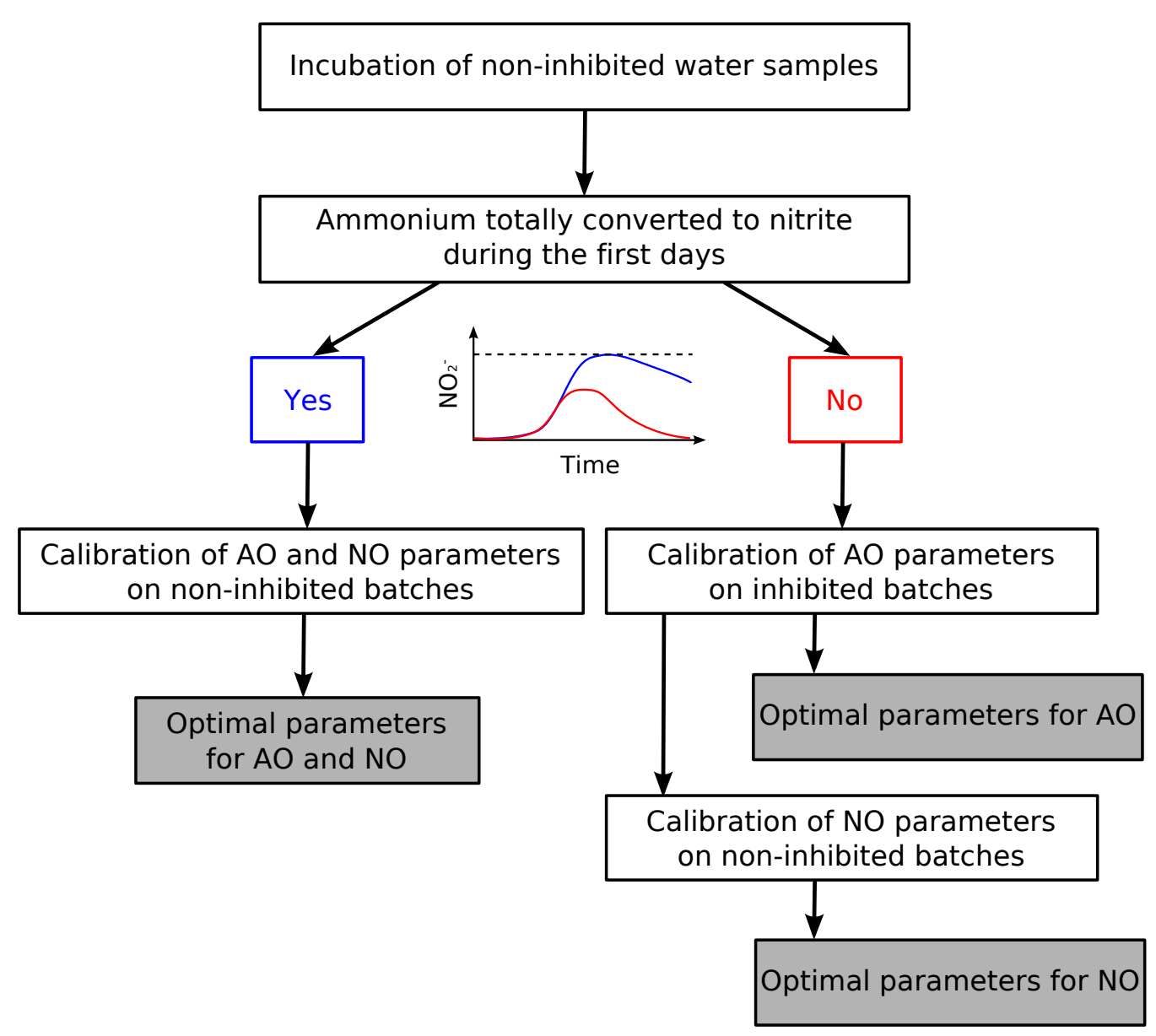

Figure 2: Procedure to find optimal kinetic parameters (growth rate, half-saturation constant) and initial biomasses of $\mathrm{AO}$ and $\mathrm{NO}$.

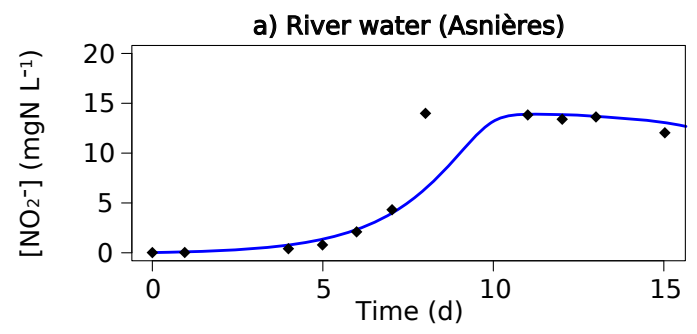

b) SAV WWTP

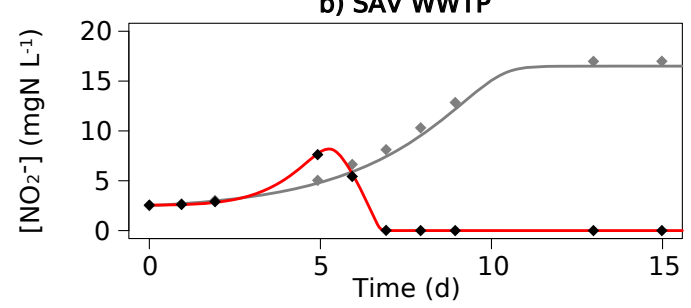

Figure 3: Best adjusment of nitrite concentrations-time curves during nitrification incubations (a) at Asnières, and (b) in the SAV WWTP effluent in November 2012. Points and curves represent data and model best adjustment results, respectively. The blue and red lines are the best adjustment on non-inhibited batch, and the grey line is the best adjustment on batch inhibited for nitrite oxidation. 

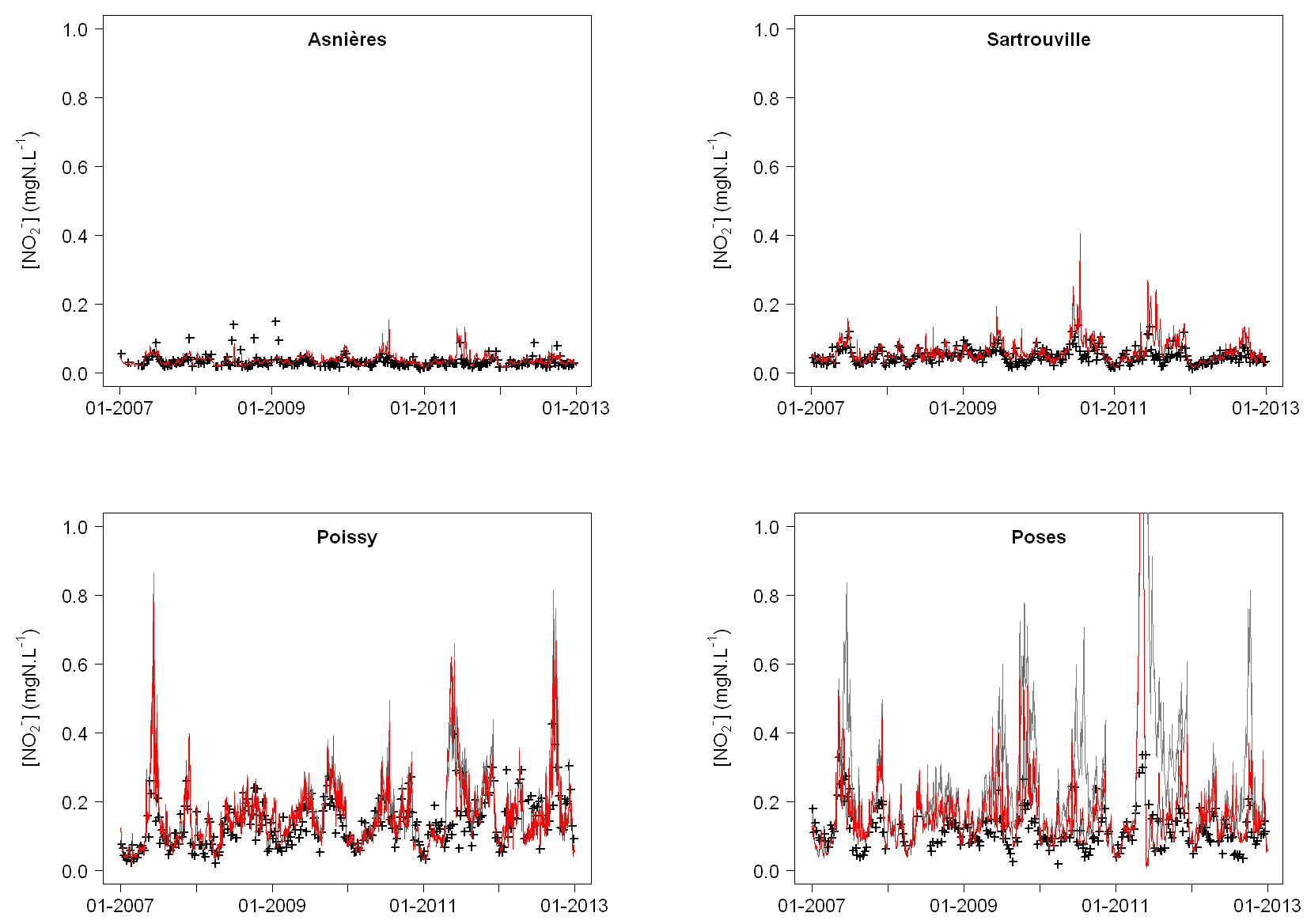

Figure 4: 6-year time-series of $\mathrm{NO}_{2}^{-}$concentrations at 4 stations from Paris to $200 \mathrm{~km}$ downstream. Red lines $=$ simulated concentrations with Seine river and WWTP nitrifier communities, gray lines = simulated with micro-filtration of the WWTP effluent. 

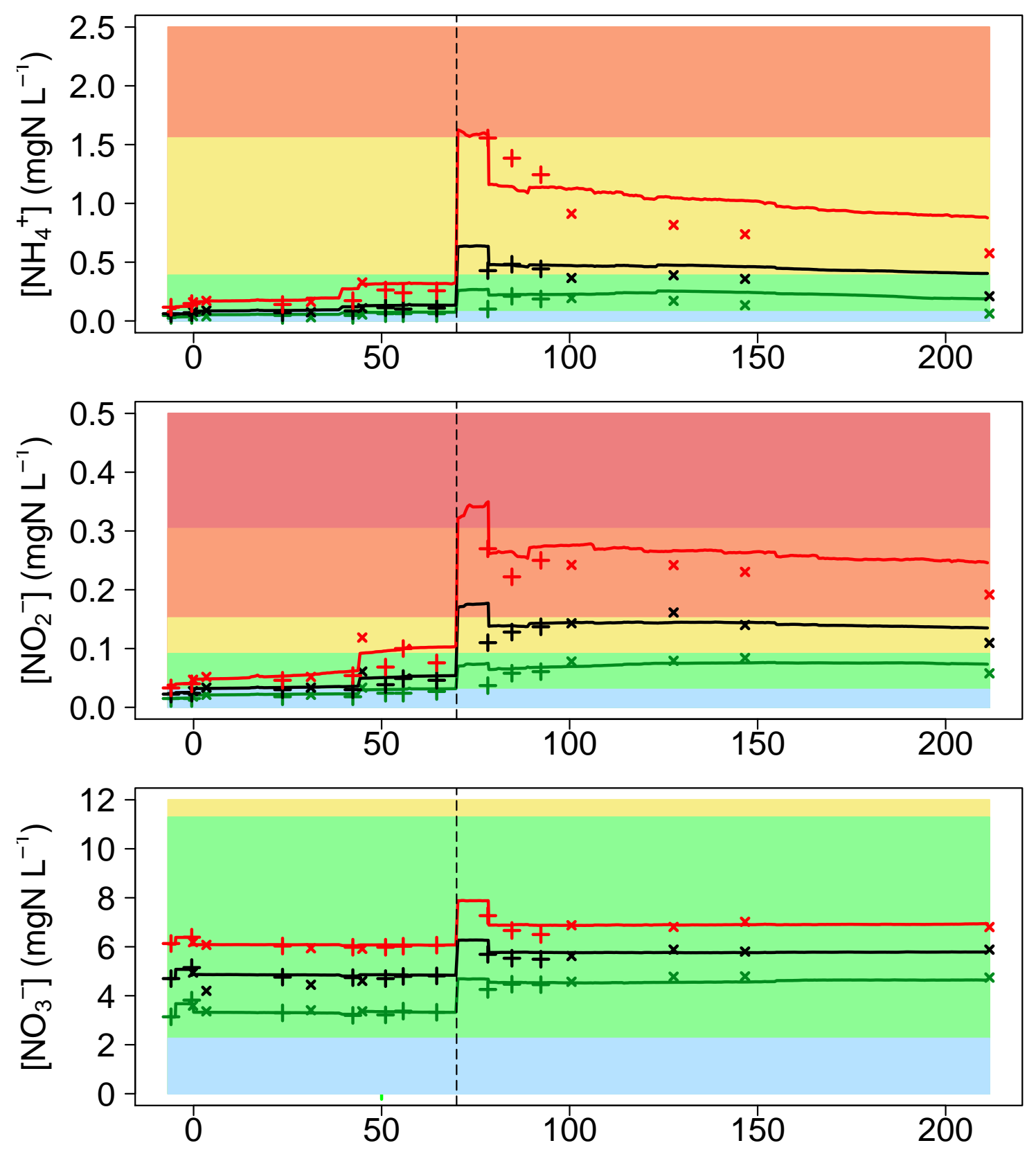

Figure 5: Longitudinal profiles of median and $10 \%$ and $90 \%$ quantiles of 6 -year $\mathrm{NO}_{2}^{-}$concentrations (black, green and red points and lines). $\times=$ RCS data $+=$ SIAAP data; lines $=$ model outputs. Each color band refers to water quality level according to the EU WFD. Blue and red are the extreme very good and bad status. 

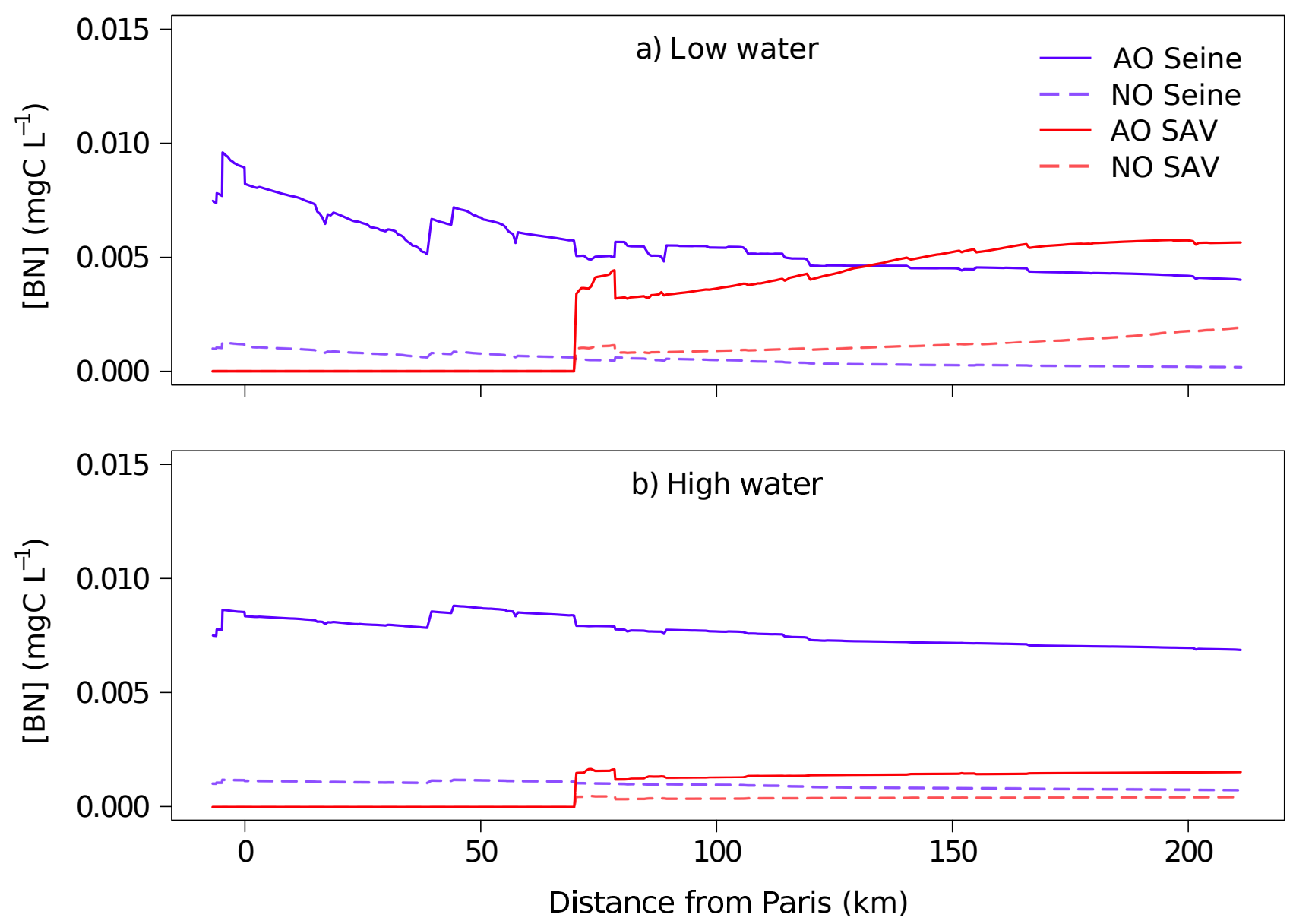

Figure 6: Biomass of active ammonia and nitrite oxidizing communities (a) in low water and (b) high water conditions. 


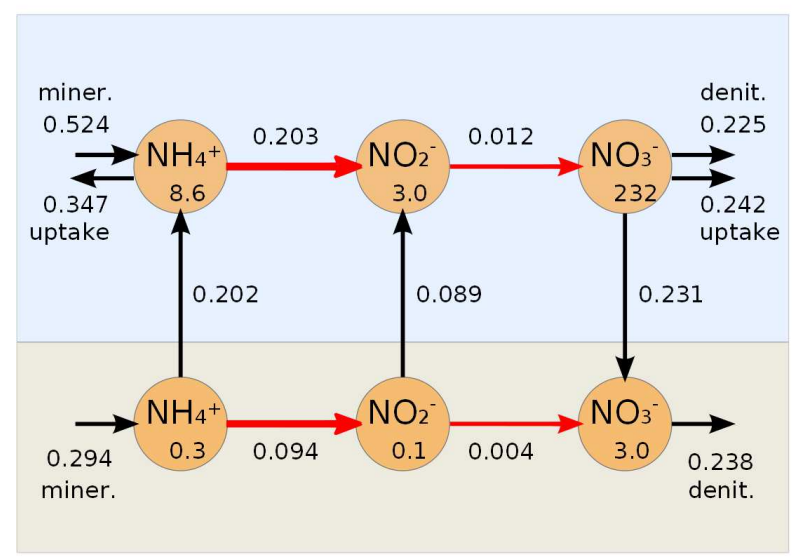

High water conditions - upstream SAV

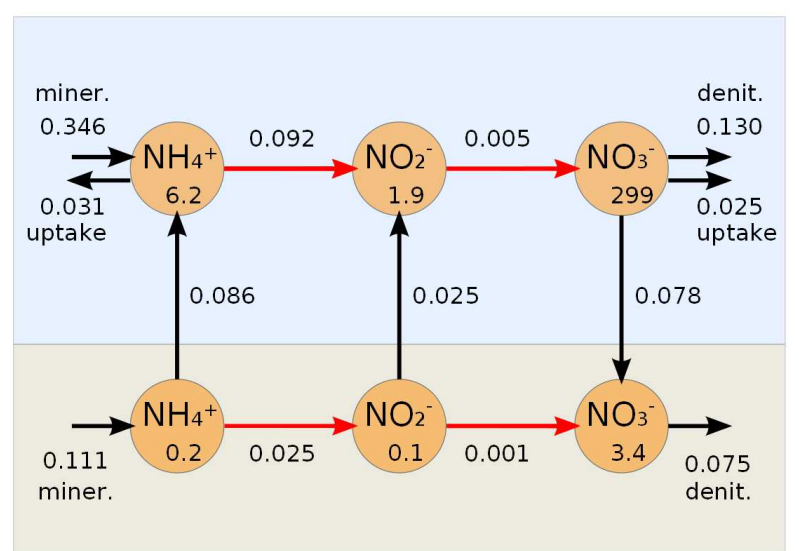

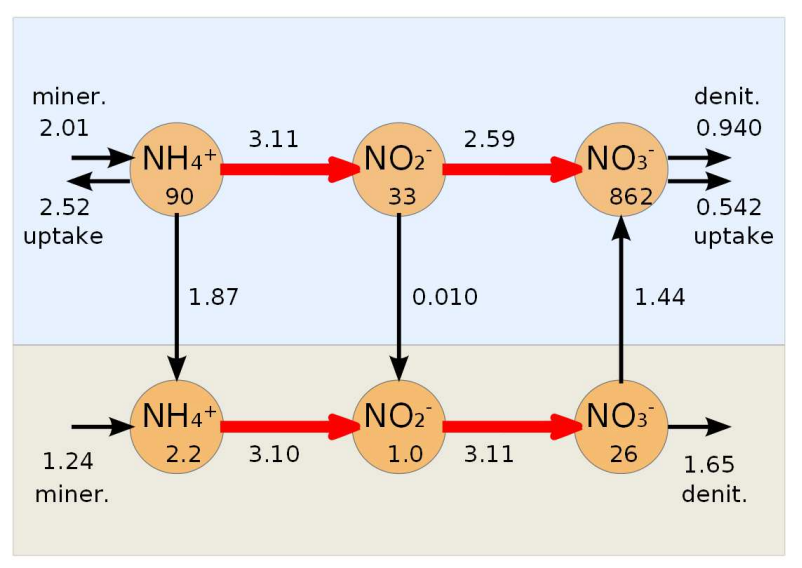

High water conditions - downstream SAV

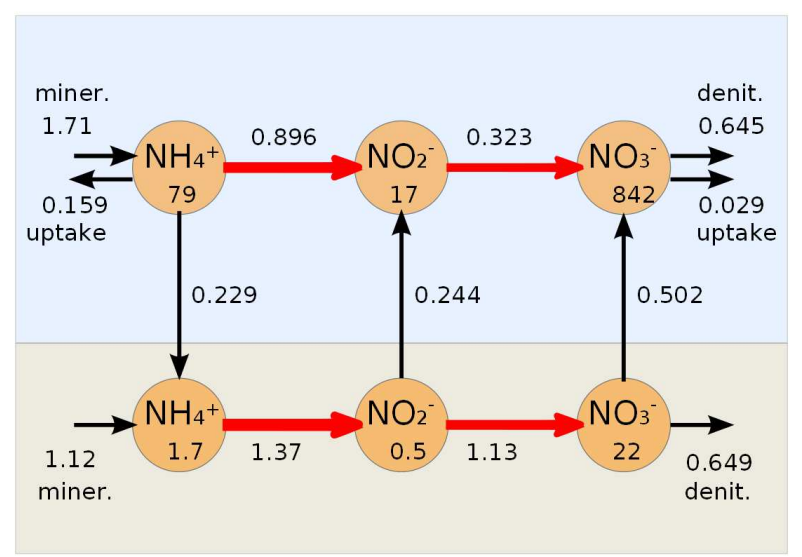

Figure 7: Nitrogen budget in the Seine River, upstream and downstream the SAV WWTP, in low and high water conditions. Stocks are in $\mathrm{TN}$ and fluxes are in $\mathrm{TN} \mathrm{d}^{-1}$. Ammonia and nitrite oxidation fluxes are in red. Mineralization (miner.), phytoplankton uptake (uptake), denitrification (denit.) and benthic fluxes (arrows between water and sediment compartments) are in black. 
Appendix
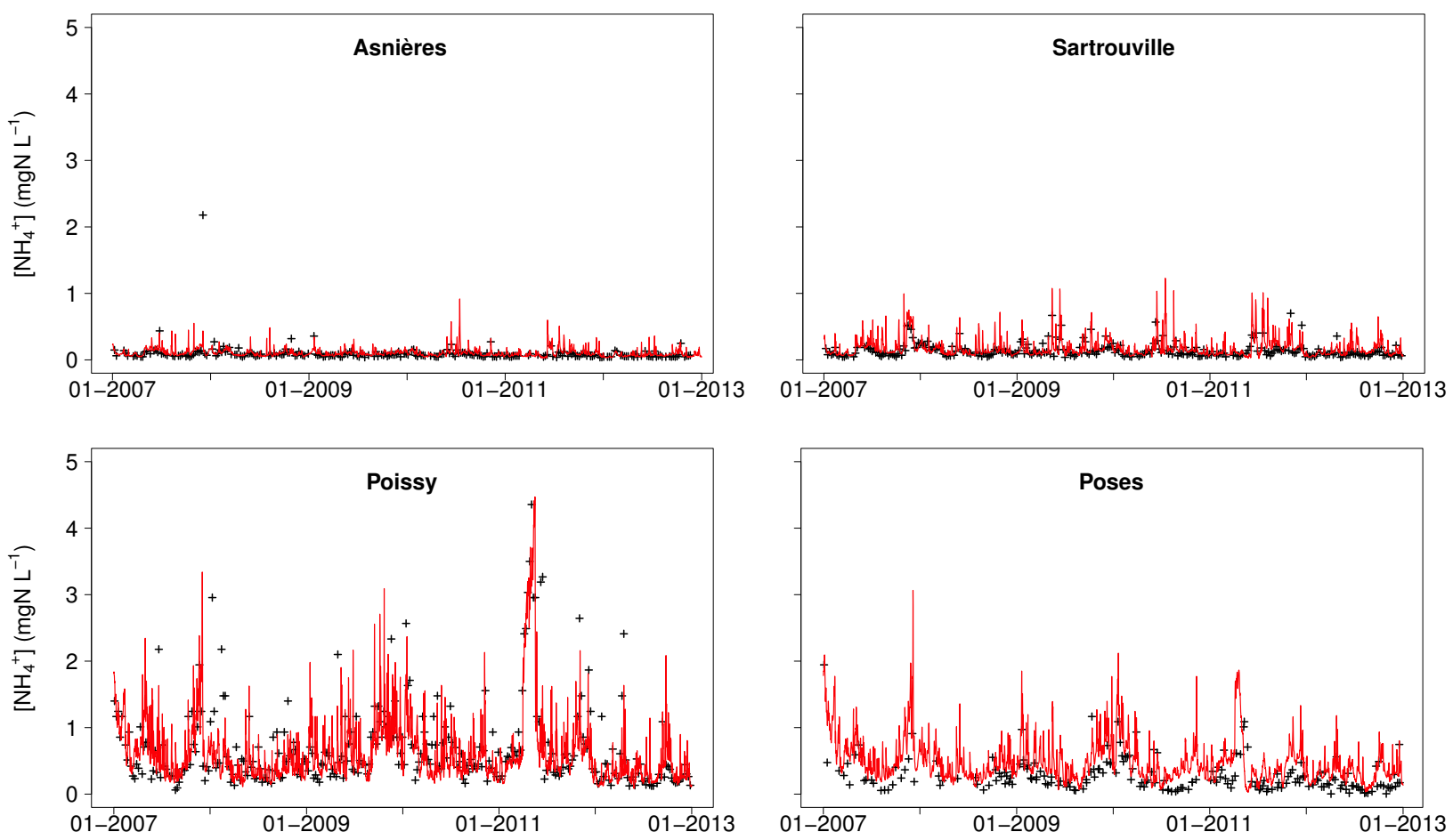

Figure A.1: 6-year time-series of $\mathrm{NH}_{4}^{+}$concentrations at 4 stations from Paris to $200 \mathrm{~km}$ downstream.

Table A.1: Statistical criteria (RMSE in $\mathrm{mgN} \mathrm{L}^{-1}$ ) for 6 -year $\mathrm{NH}_{4}^{+}$time-series at the four monitoring stations shown in Fig. A.1. LW = low water conditions, $\mathrm{HW}=$ high water conditions.

\begin{tabular}{lccc}
\hline Station & LW & HW & 2007-2012 \\
\hline Asnières & 0.060 & 0.164 & 0.123 \\
Sartrouville & 0.115 & 0.072 & 0.096 \\
Poissy & 0.404 & 0.404 & 0.404 \\
Poses & 0.328 & 0.306 & 0.318 \\
\hline
\end{tabular}



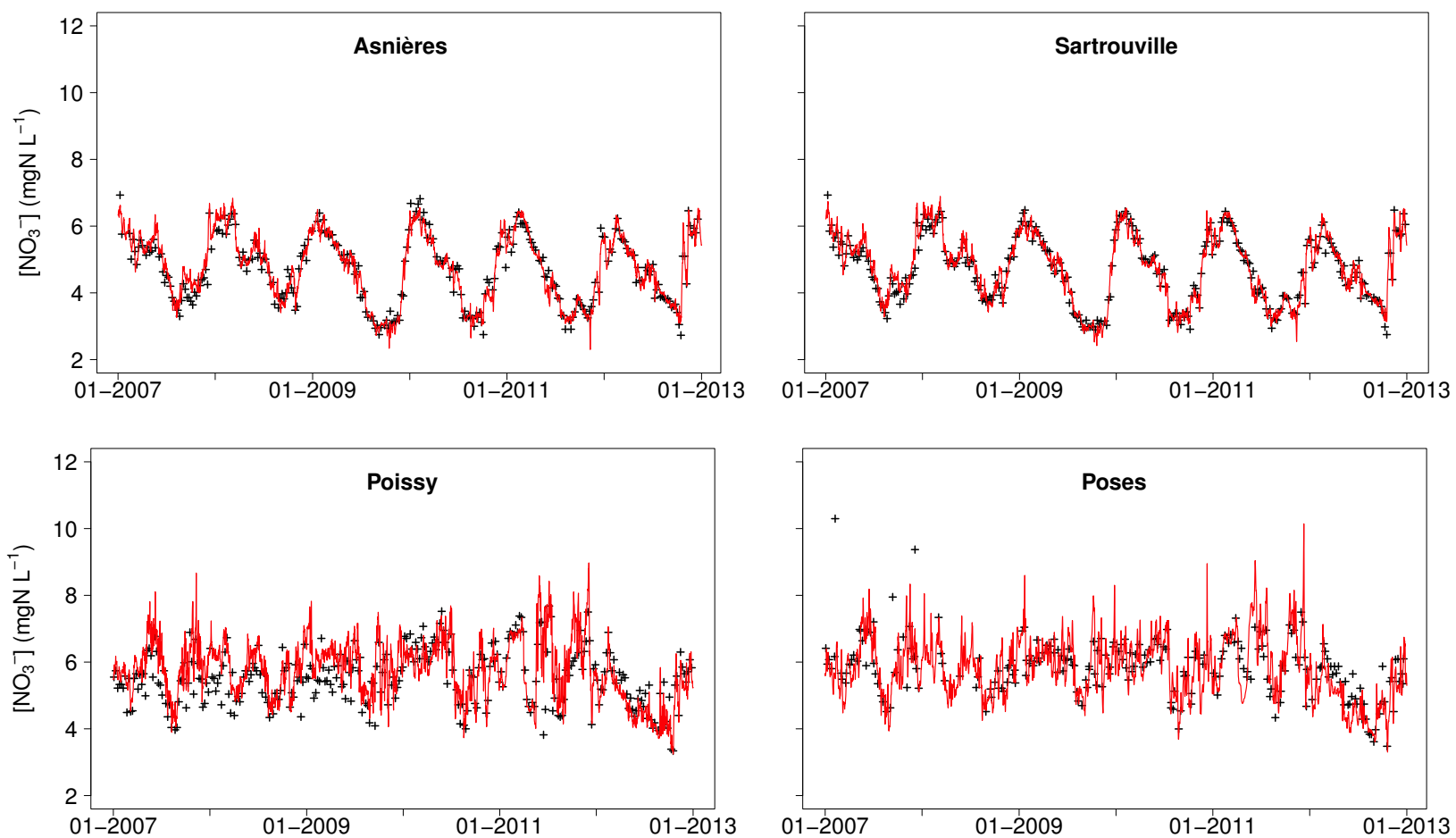

Figure A.2: 6-year time-series of $\mathrm{NO}_{3}^{-}$concentrations at 4 stations from Paris to $200 \mathrm{~km}$ downstream.

Table A.2: Statistical criteria (RMSE in $\mathrm{mgN} \mathrm{L}^{-1}$ ) for 6-year $\mathrm{NO}_{3}^{-}$time-series at the four monitoring stations shown in Fig. A.2. LW = low water conditions, $\mathrm{HW}=$ high water conditions.

\begin{tabular}{lccc}
\hline Station & LW & HW & $2007-2012$ \\
\hline Asnières & 0.233 & 0.277 & 0.256 \\
Sartrouville & 0.218 & 0.213 & 0.215 \\
Poissy & 0.587 & 0.485 & 0.537 \\
Poses & 0.629 & 0.702 & 0.663 \\
\hline
\end{tabular}



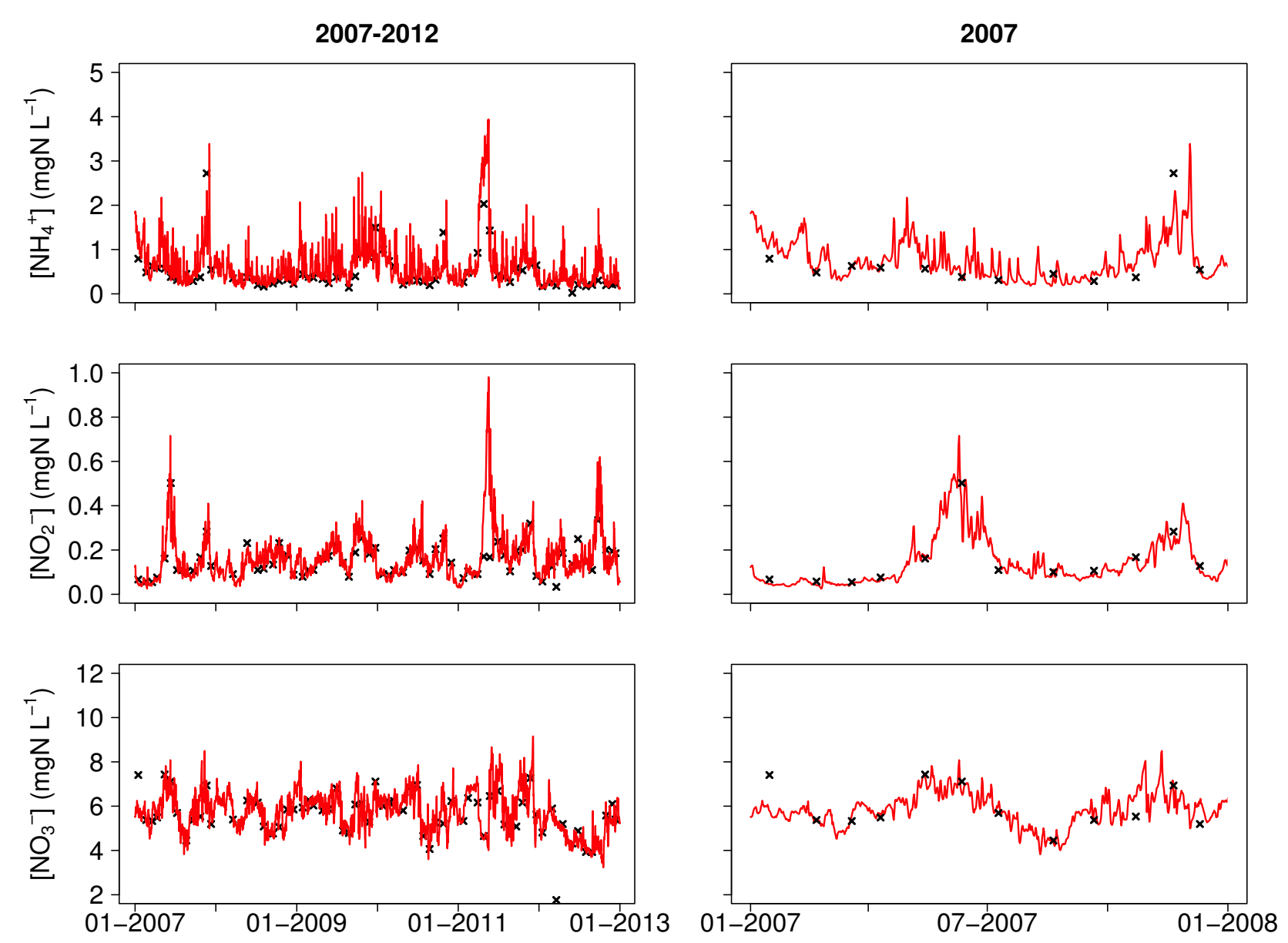

Figure A.3: 6-years and 1-year time-series of $\mathrm{NH}_{4}^{+}, \mathrm{NO}_{2}^{-}$and $\mathrm{NO}_{3}^{-}$concentrations at Meulan. Crosses are data from the RSC monthly monitoring program. 